NBER WORKING PAPER SERIES

\title{
DID INEQUALITY IN FARM SIZES LEAD TO SUPPRESSION OF BANKING AND CREDIT IN THE LATE NINETEENTH CENTURY?
}

\author{
Matthew S. Jaremski \\ Price V. Fishback \\ Working Paper 23348 \\ http://www.nber.org/papers/w23348 \\ NATIONAL BUREAU OF ECONOMIC RESEARCH \\ 1050 Massachusetts Avenue \\ Cambridge, MA 02138 \\ April 2017
}

The authors would like to thank Ann Carlos, two anonymous referees, Lee Alston, Charles Calomiris, and Kenneth Snowden as well as participants at Rutgers University and the NBER Development of the American Economy meetings for valuable comments and suggestions. The views expressed herein are those of the authors and do not necessarily reflect the views of the National Bureau of Economic Research.

At least one co-author has disclosed a financial relationship of potential relevance for this research. Further information is available online at http://www.nber.org/papers/w23348.ack

NBER working papers are circulated for discussion and comment purposes. They have not been peer-reviewed or been subject to the review by the NBER Board of Directors that accompanies official NBER publications.

(C) 2017 by Matthew S. Jaremski and Price V. Fishback. All rights reserved. Short sections of text, not to exceed two paragraphs, may be quoted without explicit permission provided that full credit, including $\odot$ notice, is given to the source. 
Did Inequality in Farm Sizes Lead to Suppression of Banking and Credit in the Late Nineteenth Century?

Matthew S. Jaremski and Price V. Fishback

NBER Working Paper No. 23348

April 2017

JEL No. G20,016,O43

\begin{abstract}
This paper creates a new database that covers all banks in the United States in the census years between 1870 and 1900 to test the interaction between inequality and financial development when the banking system was starting over from scratch. A fixed-effects panel regression shows that the number of banks per thousand people in the South has a strong positive relationship with the size of farm operations. This suggests that large Southern farm operators welcomed new banks after the Civil War. When the analysis is extended into the 1900s, the relationship becomes more negative, as bankers may have tried to block entrants.
\end{abstract}

\author{
Matthew S. Jaremski \\ Colgate University \\ Department of Economics \\ 13 Oak Drive \\ Hamilton, NY 13346 \\ and NBER \\ mjaremski@colgate.edu \\ Price V. Fishback \\ Department of Economics \\ University of Arizona \\ Tucson, AZ 85721 \\ and NBER \\ pfishback@eller.arizona.edu
}




\section{Introduction}

Over the last decade, there has been renewed interest in determining whether inequality affects the development of commercial banks and credit. Stanley Engerman, Elisa Mariscal, and Kenneth Sokoloff (2003) and Raghuram Rajan (2009) argue that the simple existence of a large gap between the "haves" and the "have nots" may have been sufficient to establish inefficient institutions. According to Rajan $(2009,1)$ : "When citizens in a poor constrained society are very unequally endowed, they are likely to find it hard to agree on reforms, even though the status quo hurts them collectively." Engerman and Sokoloff (2002), Douglas North, John Wallis, and Barry Weingast (2009), and Daron Acemoglu and James Robinson (2012) argue that elites in most societies use their endowments to shape institutions in order to maintain their preferred access to economic opportunities. On the other hand, they also show that some societies have successfully made the transition from governments dominated by a group of elites to open access societies where large numbers of people are free to compete and improve their economic welfare. While the United States successfully made this transition early in its development, authors such as Jonathan Weiner (1975) and Oded Galor, Omer Moav, and Dietrich Vollrath (2009) raise questions about the openness of the Southern economy after the Civil War.

Rajan and Rodney Ramcharan (2011) performed a test of the hypothesis that settings with more inequality led to restricted access to credit in lesser developed economies. Specifically, they examined the relationship between inequality in the size of farm operations and the extent of banking activity in 1920s America. They argued that elites were providing informal credit to small farmers and tenants and saw commercial banks as potential rivals in the provision of that type of credit; therefore, the elites worked to prevent commercial banks from 
developing in their areas. Their results show that greater inequality in the size of farm operations was associated with less bank activity per capita in the 1920 s.

In this paper we create a new data set that covers all banks in the United States in the census years between 1870 and 1900 to test the relationship between inequality and banks during the late nineteenth century. The test is performed during a much earlier stage of America's economic development and during a period when the provision of informal credit by local elites in the agricultural sector was at its height. The combination of the Civil War, the National Banking Acts, and a tax on state bank notes led to the general absence of commercial banks in agricultural counties throughout the nation in 1870 . The situation in the South was compounded further by the end of slavery, which led to substantial changes in the economic and institutional relationships between elites and their work force.

The paper unfolds in several steps. First, it provides an extensive review of the literature on the interaction of banks and agriculture lending during the post-Civil War Reconstruction period. The literature paints a dynamic and complex picture that varies by region. Most banks after the Civil War only provided short-term lending and most mortgages were provided by direct credit or by insurance or mortgage companies. Banks also faced minimum capital requirements that would have prevented entry in rural areas. Plantation owners, successful farmers, and local merchants often relied on short-term credit from a mixture of commercial banks, private bankers, buyers of their output, and suppliers of inventory to make it through the annual harvest. Most states had interest rate caps and commercial banks generally reduced risk by making loans to farmers and merchants who could post collateral (equipment or crop liens) or could obtain guarantees from a backer. Plantation owners, merchants, and some private bankers then provided short-run consumption credit to croppers and tenants at higher interest rates that 
reflected a combination of their own costs of credit, higher risk on consumption loans, and local market power. Various scholars disagree on how much weight to place on each factor.

Next, we examine the determinants of bank growth between 1870 and 1900, as the rural banking system was rebuilt after the Civil War and the National Banking Acts. In performing the test we use Rajan and Ramcharan's measure of inequality in agricultural areas, a Gini coefficient for the size distribution of farms run by operators including tenants and share croppers. The measure is the only one that can be consistently constructed across many census years and allows us to make comparisons in the results in our period with those from Rajan and Ramcharan. It is an imperfect measure because the census reported the farm operations on a plantation owned by one landowner as separate operations. However, in 1945 when the Census first asked about multi-unit operations, the Gini for all farm operations is strongly correlated with the Gini that takes into account multi-unit farms. Using a fixed-effects panel regression, we find that prior to 1900 the number of banks per thousand people has a strong positive relationship with the Gini coefficient in the South, and it has a weaker positive relationship across the entire nation. The lack of a strong result across the full sample of counties is to be expected as agricultural interest groups were unlikely to influence local institutions in non-agricultural areas.

The final section of the paper examines why our findings for the late $19^{\text {th }}$ century differ from Rajan and Ramcharam's findings for 1920 and 1930. We, therefore, expand our panel analysis through 1930, estimate their cross-sectional regressions for the years before 1920, and compare the institutional settings prior to 1900 and in the 1920 s in more depth. When we expand our panel by adding additional years, the positive relationship between banks and inequality is reduced when 1910 is added and the relationship becomes negative once 1920 is added. When controlling for county characteristics in the single decade cross-sections, the results do not show 
consistently negative and statistically significant relationships between inequality and the number of banks across the nation until 1910. In both the panel and cross-sectional analysis, however, land inequality is never statistically significantly negatively correlated with banks in the South when controlling for county characteristics.

Comparisons of institutional environments show that most rural counties had no commercial banks in 1870 , yet most had one bank by 1900 and most had multiple banks by 1920. The market for bank credit became more integrated as the standard deviation for crosssections of state average commercial bank interest rates fell from around five in the late 1870s to around one in 1920. Minimum capital requirements for national banks in rural areas were reduced sharply in 1900, and the federal government had begun providing seed money to enhance cooperative mortgage lending among farmers by 1920. Farmers were also more mobile with the introduction of the automobile and the percent of farms reporting automobiles rose from 31 to 58 percent between 1920 and 1930 (U.S. Census Bureau 1933, p. 530).

These findings suggest that the relationship between inequality and bank activity in rural economies changed substantially over time. In the early phases when the banking sector was starting over from scratch after the National Banking Acts and the Civil War, elites appear to have taken action to start or attract banks to build up access to credit in their counties. After 1900 when nearly all counties had at least one bank and many had multiple banks, it looks more like a situation where the elites who were trying to stop bank entry were the bank owners themselves rather than the plantation owners and merchants who were making consumption loans to croppers and tenants. After all, many of the plantation owners and merchants were themselves 
borrowing from the banks and likely would have welcomed more competition among bankers when seeking credit. ${ }^{1}$

\section{Rebuilding the Commercial Banking System in the Post-bellum Period}

Access to existing state banks (including state banks, trust companies, and savings banks) was virtually eliminated in the nation's agricultural areas during the 1860s. Nearly all Southern banks closed during the Civil War, whereas many rural Midwest banks closed after a prohibitive tax on state bank notes was passed in 1865 (Jaremski 2013). Following the Civil War, national banks began to be organized and state banks rebounded. The number of incorporated banks grew from around 2,000 banks to over 10,000 by 1900, but as seen in Figure I, growth was often concentrated in the Northeast and Midwest, largely bypassing Southern agricultural areas. Even as late as 1900, 30 percent of Southern counties did not have a bank, compared to 15 percent of non-Southern counties.

Largely due to their lack of a formal charter or specific regulation, private bankers fared somewhat better over the Civil War. Their number nearly doubled between 1860 and 1870 . According to George Barnett (1911, p. 206), private bankers were individuals or businesses that generally functioned "(1) As an adjunct to the brokerage business in large cities; (2) as a means of furnishing credit in small communities, chiefly in agricultural sections". They typically had very small capital levels and operated in locations where there was not sufficient capital or people to create an incorporated bank. That said, while private brokerage banks expanded in financial centers such as Chicago and New York City, the growth of private bankers across

\footnotetext{
${ }^{1}$ The most obvious example of local banks seeking to block entry was their adamant opposition to branch banking, which would have allowed larger banks to enter many local markets by opening branches in competition with local unit banks (White 1982, p. 38). Calvin Coquillette (2001) provides a detailed description of the attempts by Iowa bankers to block branching and new forms of competition in the 1920s and early 1930s.
} 
agricultural areas was slow over the late 1800s, especially as capital requirements of state and national banks were lowered. The South for instance, had 289 private bankers in 1877, 416 in 1899, and 438 in 1909 (Barnett 1911).

There are several potential reasons why banks did not quickly return to agricultural areas after the Civil War. National banks were largely prohibited from providing loans on real estate, and banks in general tended to make short-term loans to financial operating expenses rather than long-term mortgages, which advocated short-term, self-liquidating loans. Therefore, unlike the 1920s decade studied by Rajan and Ramcharan, the majority of bank loans before 1900 provided operational and seasonal liquidity rather than long-term mortgage debt. Kenneth Snowden (1995, Table 7.1, p. 220) reports that only 30 percent of all U.S. mortgage debt around 1890 was provided by financial intermediaries, and the share was lowest in the agricultural South (12 percent) and Midwest (28 percent). Moreover, most of the mortgages in these agricultural regions were from building and loans, life insurance companies, and large mortgage companies rather than standard banks.

Lewis Haney (1914) and Richard Keehn and Gene Smiley (1977) argue that some national banks circumvented the restrictions, but the evidence indicates that mortgages at national banks were relatively uncommon. Indeed, state banks lent a much larger proportion and value of their funds on real estate. According to the Board of Governors of the Federal Reserve System (1959), over 40 percent of all loans by state banks, trust companies, and savings banks in 1896 were on real estate compared to 9 percent by national banks. While the Board of Governors of the Federal Reserve System only list private bankers for a few states, the data suggest that they provided relatively few mortgages. This is not entirely unexpected, as private bankers were 
likely too small to provide the level of credit needed to provide many mortgage loans and likely provided mostly short-term loans.

National bank capital requirements and a prohibitive tax on state bank notes are a frequently cited reason for the lack of incorporated banks in rural communities (Sylla 1969). The National Banking Act of 1864 required national banks in a city with more than 50,000 people to have $\$ 200,000$ in capital, those with 6,000 to 49,999 people to have $\$ 100,000$, and those in smaller cities to have $\$ 50,000 .{ }^{2}$ The intent was to prevent risky and undercapitalized banks from arising, but the result was the elimination of national banks in many rural areas. Alternatively, state banks generally had lower capital requirements but their inability to issue bank notes slowed their growth until deposit accounts became more popular. ${ }^{3}$ As a result of these factors private bankers often were able to operate in rural areas without much competition from incorporated banks.

Even in the short run agricultural lending was inherently risky. Bad local weather or good foreign weather would dramatically affect farmers' ability to repay their loans. Barry Eichengreen $(1984,1987)$ and Snowden (1987) argue that greater risk and higher transactions costs contributed to higher interest rates on mortgages in the West and South than in the East in the early 1890 s. ${ }^{4}$ While we lack loan default data for banks, the high failures rates of local merchants, which generally provided small and short-term loans support the argument that lending for consumption credit was risky. For instance, Scott Marler (2011, pp. 231-234) finds

\footnotetext{
${ }^{2}$ Eugene White (1982) provides a description of the regulations and their effects.

${ }^{3}$ National bank note profitability also declined over time as the collateral used to back the notes (in other words U.S. Treasury bonds) were becoming more expensive and checking accounts became more common (Jaremski and Rousseau 2015).

${ }^{4}$ Virgil Lee (1930, p. 273-300) documents how higher administrative costs and loss ratios for commercial banks affected both access to credit and interest rates across regions for the period 1914 to 1926.
} 
that only 35 percent of the 72 stores in a Louisiana cotton county established between 1863 and 1878 survived until 1878, and only 52 percent survived in a Louisiana sugar county. ${ }^{5}$

Additional banking regulations decreased the return and increased the risk of agricultural lending. Reint Gropp, John Scholz, and Michelle White (1997) argue that laws preventing the seizure of homes discouraged banks from providing loans secured by real estate, whereas usury laws effectively prevented them from lending to small risky farmers without collateral. Charles Calomiris and Carlos Ramirez (2004) and Mark Carlson and Kris Mitchener (2006) argue that the general absence of branch banking prevented banks from diversifying their loan portfolios across agricultural regions. ${ }^{6}$

The accumulation of all these factors led to a slow recovery of banks after the Civil War, and a complicated story of how agriculture was financed in the postbellum period. Indeed, as seen in the next section, the financing not only varied across the various types of banks but also across the various regions of the country.

\section{Sources of Credit, 1865-1900}

When the Civil War ended, slavery and soldiers returned to civilian life, America was on the cusp of a rapid expansion in agriculture. Between 1870 and 1900 the number of farms and the acreage planted on farms nearly doubled as a result of transportation improvements and the series of Homestead Acts. This rapid expansion in farming intensified the demand for credit. Opening up new land for production involved extensive up-front investment in work, time, and capital before the land would be arable. Most farmers took out large loans to purchase land as

\footnotetext{
${ }^{5}$ The evidence comes from R.G. Dun merchant reports in the 1870s. Marler (2011) finds similar results when he expands the sample to the whole state.

${ }^{6}$ Even as late as 1920, national banks could not branch and only 16 states allowed branching of state banks (Dehejia and Lleras-Muney 2007).
} 
well as machinery and work stock to start a farm. Since payments for a successful harvest came after the farmer had incurred all of the expenses for the year, tenants, croppers, and even established farmer owners also extensively used small loans to pay for annual farm expenses like seed, hiring of labor, and purchases of tools. They then typically repaid the loans after the harvest ended. ${ }^{7}$

Substantial agricultural growth occurred in nearly every state; however, the composition of growth differed across regions. ${ }^{8}$ In the Midwest and West, there was a large amount of open land and eastern migrants often had some cash and education to start their farms. As a result, most farms were family farms with a mixture of owner operators and cash and share tenants. In the South, there was less available land and most freed slaves had no cash or education. Existing owners sought new ways to work their land and non-landowners struggled to purchase their own land. Some landowners farmed their land with the help of unpaid family workers, but many former plantation owners hired wage labor, brought in share croppers who were laborers working a specific plot for a share of the crop, or rented land to share tenants for a share of the crop or cash tenants for a fixed payment. These differences led to differences in the way credit was supplied.

\section{Credit in the Midwest and West}

In the West and Midwest the void for farm mortgages left by commercial banks was largely filled by other institutional sources of credit. John Hicks (1931, pp. 7, 20-21) describes a farming boom fueled by ample mortgage credit from railroads and mortgage brokers in the late

\footnotetext{
${ }^{7}$ Savings and credit also helped farmers advance up the tenure ladder over their lifetimes. Even with credit, however, climbing the agricultural ladder was no easy process because low crop yields and low prices often forced people back to lower rungs.

${ }^{8}$ See series Da1-Da224 in Susan Carter et al. (2006, pp. 4-39 to 4-53).
} 
1860s and early 1870s. Railway companies offered credit in selling off their lands, and farmers settled the public lands under the rules of the Homestead Act of 1862. After some hard times in the mid to late 1870 s, western farming boomed again in the 1880s. Larger mortgage companies developed central offices in major cities and had local agents in many smaller farm communities. ${ }^{9}$ In the late 1880 s there were between 137 and 200 mortgage corporations in Kansas and Nebraska. In 1890 Kansas, Nebraska, North and South Dakota, and Minnesota all ranked in the top nine states in terms of per capita mortgage debt. By the early 1890s insurance companies were making 23 percent of the mortgages in the West North Central and 33 percent of the mortgages in the West South Central regions (Snowden 1995, Table 7.1, p. 220).

Banks provided short-term credit for production for larger farms as well as landowners and tenants with assets and good credit history. Most banks typically did not lend to owner operators and tenants without collateral, support from others, or a strong vetting of the borrower (James Mormon 1924, pp. 287-312; Lee 1930, pp. 65-170, 273-322; see also Haney 1914 for Texas). Owners could put up their land as collateral, while both tenants and owner-operators could use mules and tools as collateral. Although pure consumption or emergency loans were generally considered too risky, owners and tenants who had good records and were already borrowing for mules and tools typically could draw credit for family consumption purposes with collateral in the form of work stock, warehouse receipts, crop liens or personal notes. This smaller credit was typically drawn in amounts of $\$ 50$ to $\$ 100$ as needed, thus the farmer could reduce the interest payments by delaying borrowing until the cash was needed. ${ }^{10}$ Local merchants often filled the void for smaller owner/operators and tenants by providing store credit in return for promissory notes or the crop liens. The merchants themselves often borrowed from

\footnotetext{
${ }^{9}$ See Allen Bogue (1955) for more information on mortgage companies.

${ }^{10}$ Reports based on evidence from the 1910s and early 1920s show that these loans were riskier and involved higher administrative costs per dollar loaned and thus carried higher interest rates.
} 
banks and their own vendors using store goods, promissory notes, and crop liens from their customers as collateral.

Common in city and country stores, store credit often came in the form of higher prices for credit purchases than for cash purchases. Interest rates on store credit were substantially higher than on bank credit for multiple reasons: (1) Merchants themselves were borrowing funds and would seek interest rates higher than their borrowing costs. (2) Store customers had lower incomes, little or no collateral to offer, and were borrowing for consumption purchases, which meant the customers had little to offer if the crop failed and they could not pay off the store debt. (3) Merchants had more short-run market power in counties with fewer stores.

\section{Credit in The South}

Due to the readjustment of agricultural after the abolition of slavery as well as the virtual loss of banking during the Civil War, the expansion in farming was delayed by a decade or more in the South relative to the Plains and Western states. ${ }^{11}$ M.B. Hammond (1897) and Haney (1914) show that the planters and merchants in the 1870s and 1880s and in Texas circa 1910 heavily relied on credit from financial intermediaries and cotton brokers. Before the Civil War most planters obtained credit from cotton factors in southern ports, the Northeast, and England. After the War the factors tried to reestablish the same arrangements, but postwar problems with labor, output, and cotton prices caused substantial losses on both sides. The primary creditors to planters and merchants thus became cotton brokers who mediated between the textile manufacturers and farmers. The cotton brokers and leading northeastern and English manufacturers established offices in major southern cities and sent out agents to negotiate for the

\footnotetext{
${ }^{11}$ See Carter, et. al. (2006, pp. 3-209, 3-183 to 3-185, 4-51 to 4-53) and George Holmes and John Lord (1895, p. 29).
} 
coming year's crops. Particularly after the war, neither the large landlords nor the merchants had enough cash or capital on hand to survive the long season between the planting of the crop and the harvest, so they often borrowed from the brokers and textile manufacturers using their property and the coming crop as collateral. In a number of cases they consigned a share of the anticipated crop to specific brokers and companies in return for advances that would allow them to survive the year and also provide credit to tenants, croppers, and small land owners. In fact, Hammond (1897, pp. 143-144) describes a situation where the crop lien was a savior for the landlord and merchant as they could use their crop liens on tenants, croppers, or small farmers as collateral when applying for their own seasonal credit loan (see also Woodman 1999, pp. 302309). From a bank's perspective, owner operators and/or landlords were the best borrowers. The most detailed description of banking behavior in the rural south was provided by Haney (1914) for Texas around 1910-1913. While this is later than our period of focus, it provides insight into the conservatism that commercial banks followed when lending. Haney claims that roughly 95 percent of farm owners borrowed from banks, typically year after year. ${ }^{12}$ Most of the loans made by banks to land owners were to "make the crop", and roughly 90 percent of loans were secured by collateral, like mules and tools and crop liens. The usual items funded by these loans were feed, seed, groceries, and perhaps mules. Haney compares large loans over $\$ 1,000$ with those for $\$ 50$ or less. The large loans were typically made on machinery or land. The small loans were typically for labor, feed, and seed costs, with some going to the purchase of mules, plows and improvements. Only one eighth of the small loans were consumption loans of the type that merchants offered and these were typically only made to farmers who had already borrowed from the bank for other purposes. Farmers typically borrowed

\footnotetext{
${ }^{12}$ Haney (1914) provides the best description that we have found of the credit structure. It is important to put his survey in context because Texas had a relatively large number of banks compared to other southern Cotton states at the time. Further, the period was 1912, nearly 50 years after the end of the Civil War.
} 
a total of about $\$ 300$ for the year in smaller increments with the modal and mean small loans lasting about 3 months. The most common interest rate on long term loans was about 9.3 percent, while the shorter loans were at 10.8. Even though the usury law rate was 10 percent, reports from farmers claim rates of 10.7 for large loans and 13 for small loans. The most common rate was 11.1 percent after taking into account that all interest was paid up front on the loan. (Haney 1914)

In Haney's data banks most commonly made about 50 percent of their loans to tenant farmers. However, the value of the loans to tenant farmers accounted for only about five percent of the total value of the banks' loans. Tenant farmers borrowed multiple small loans of $\$ 50$ to \$75 dollars that aggregated up to between \$200 and \$600 to "make the crop." The loans were typically for about 7-9 months with chattel mortgages on teams, stock, implements, and crops and "not infrequently" the personal security of the landlord or of a friend. "Tenant farmers with good standing and acceptable collateral" could typically borrow at 8 to 10 percent but would pay from 10 to 30 percent when borrowing from “outside parties” (Haney 1914, p. 51).

Haney (1914, p. 51) considered store credit and crop liens to be a "dark place in the Texas farm credit system." Fewer than 10 percent of farm owners but nearly all black tenants and 75 to 90 percent of white tenants regularly depended on advances from the local storekeeper for food, clothes, and various supplies, and posted their crop and any other property they may own, if they owned. The merchant rationed the credit based on the amount of acreage and the anticipated productivity of the borrower. Nearly all of the tenants involved with the store also borrowed from their landlord for mules, feed, and other expenses. Where present, large plantation owners typically preferred to lend to their tenants and croppers so that they could 
maintain more control over the crop choices and operations of their tenants and croppers

(McGuire and Higgs 1977).

\section{Landlords' Interest in Preventing Banks}

Roger Ransom and Richard Sutch (1972, 1977), Hicks (1931), Weiner (1975) and Pete

Daniel (1973) all suggest that the informal consumption credit provided by merchants and landlords were highly profitable for the lender, and Rajan and Ramcharam (2011) argue that powerful landlords and merchants worked to keep banks from entering to allow them to maintain these high profits. Peter Temin (1979), Claudia Goldin (1979), Price Fishback (1989), and Gavin Wright (1986, pp. 111-113) all, however, argue that the profitability of these loans was limited by the mobility of tenants and croppers, who typically paid off their consumption loans at harvest and could switch stores when seeking credit the next year. ${ }^{13}$ Haney (1914) and Hammond (1897, 142-143) also argue that the loans were profitable, but they also point out that the merchants and landlords borrowed funds to finance the credit they offered. ${ }^{14}$ The interest paid by merchants to banks was usually 8 percent. As security, the merchants endorsed and turned over to the banks the farmers' notes and crop mortgages as collateral at a discount value. Haney (1914, p. 54) concludes that 'the country merchants act as the banker's agents in making crop mortgage loans."

\footnotetext{
${ }^{13}$ For the first time in 1940 the U.S. Census asked people where they had lived five years earlier. In the southern states between 1935 and 1940 the one-percent IPUMS sample shows that 48.5 percent of people on farms in 1940 had changed houses within the same county, 6.7 percent had changed counties within the same state, and another 7.2 percent had come from outside the state. This is much later than the period we study, but comparable estimates of migration between the 1850s and 1980s show that the 1930s was the decade with the lowest internal migration rates. The cross decade comparisons are based on differences in state of residence and birth state by Joshua Rosenbloom and William Sundstrom (2004) who document that people listed in the 1940 Census were less likely to be living in a state aside from their birth state than in any other census year between 1850 and 1990.

${ }^{14}$ Haney (1914) also found that between 5 and 20 percent of loans made by Texas banks were made to "country merchants, such loans being "largely" or "almost entirely" used to carry farmers on crop mortgage security.
} 
Temin (1979), Goldin (1979), Haney (1914), and Hammond (1897) all find that the

higher interest rates on the consumption loans were associated with higher risk. After noting that stores might have profited from high credit prices, Hammond $(1897,156)$ states "[A]nd yet it is questionable whether the business of merchandising in the South presents such great possibilities of becoming speedily wealthy as the above price quotations would seem to indicate." After describing the dishonesty of many purchasers offered credit by merchants, he argues:

the danger of losses involved by doing business on credit with this class of purchasers has been the prime cause of the great difference between cash and 'time' prices, while the frequent failures of advancing merchants, and the unsettled accounts which even the most careful and shrewd of those merchants are obliged to carry over from year to year, do not furnish proof to the statement that, 'the road to wealth in the South, outside of the cities and apart from manufactures, is merchandising.'

Marler (2011) shows that country stores of all sizes and credit ratings faced failure rates ranging from 12.5 to 42 percent for different size categories in Louisiana in the $1870 \mathrm{~s} .{ }^{15}$ Would the banks have stepped in to replace the merchants and landlords in providing such consumption credit? Haney (1914) says no because the banks did not want to make the small 9-month loans with only the crop as collateral because they did not want to closely supervise the operation of small farms. He argues that the banks would rather make the loan to the merchant or landlord and let them perform the supervision. This is one reason why merchants and landlords were still

\footnotetext{
${ }^{15}$ In the Dun credit ratings of the Louisiana stores in Marler's sample for the $1870 \mathrm{~s}, 81$ percent had low ratings of 3 and 3.5, 17.4 percent had 2 or 2.5 , and only 1 percent had a rating a strong as 1.5 . Store owners with more net worth typically had the highest ratings, but even large stores failed. Store failure rates were 20 percent for stores with $\$ 50$ to $\$ 100$ thousand dollars in net worth, 12.5 percent in the $\$ 25-50$ thousand category, 23 percent for the $\$ 10-25$ thousand range, 29 percent for the \$5-10 thousand range, 24.4 percent for the $\$ 2-5$ thousand range, 42 percent for the \$1-2 thousand range, and 29.4 percent for under a thousand dollars. Ransom and Sutch (1977) also documented high failure rates and show that there was wide dispersion in the location of stores. In many places there was only one store, although the store may have faced competition from planters. Ransom and Sutch argued that the high failure rates and dispersion were signs of market power, but Peter Fitzrandolph (1981) found that the same facts fit a model of spatial competition that limited market power. Even if there were market power, the low Dun credit ratings and the high probability of failure for all types of stores suggest that the stores borrowed at higher interest rates that reflected higher risk and these costs were passed on to the consumption borrowers who were buying from the store. As noted by Haney (1914) and Hammond (1897) the additional premium in implicit interest for consumption borrowers reflected the risk of nonpayment.
} 
providing consumption credit in the 1920 s, long after the entry of numerous banks into many agricultural counties (Morman 1924; Lee 1930). The expansion of commercial banks thus likely would not have had much impact on these loans because they would not have made these types of loans.

The entry into banking in agricultural areas was likely to have been driven by expansions in the number of farms and the amount of farmland under cultivation by owners and tenants who had land, mules, and tools that could be used for collateral. Although Rajan and Ramcharan (2011) seem to suggest that the new banks would have been started by outsiders, another possibility is that successful local landowners and merchants with capital were likely to be the ones to start the banks, sometimes in conjunction with outside investors. Hammond (1897, p. 161-2) describes just such a process in a number of counties in South Carolina in the 1870s when a group of local landowners joined together to start their own banks. Larry Schweikart (1987, p. 210) notes "Merchants, factors, and banks seem to have changed places frequently throughout the South. Even a switch from planter to bank to merchant, then back to planter again, was not unusual in the less urban areas." Indeed, many merchants became landowners as they kept some of the underlying land acquired from defaulted loans, and then eventually moved into banking as they expanded their business. Local merchants and landowners had an advantage over outsiders because they knew the potential customers and the structure of opportunities in the area. ${ }^{16}$ Further, starting a local bank raised the possibility that the landowners and merchants could diversify their investments and help them finance more diverse economic activities.. Recent studies show that the presence of a bank led to future growth in output and population in the

\footnotetext{
${ }^{16}$ Dodi and Schweikart (1991, pp. 25-27) suggest that a significant share of western banks were started by local merchants who had started lending and created banks to expand their businesses. Jeremy Greenwood and Boyan Jovanovic (1990) suggest the existence of this behavior as does the long history of "insider lending" practiced by banks owned by entrepreneurs in the antebellum Northeast (Lamoureaux 1996).
} 
1800s (Bodenhorn and Cuberes 2010, Jaremski and Rousseau 2013). It therefore is just as likely that the local elites, particularly successful ones, would be interested in starting a bank as it would that they would try to prevent a bank from starting. Ultimately, the relationship between large landowners and financial development is an empirical question that must be tested to determine the answer.

\section{Data on Banks and Agriculture}

The lack of county-level bank data for the late $19^{\text {th }}$ century has prevented a comprehensive examination of U.S. agricultural and banking. Seminal financial studies by Lance Davis (1965), Sylla (1969, 1975), and John James (1976a, 1976b) focus on regional differences in interest rates, whereas the few bank-level studies focus only on small geographic areas (Scott Redenius 2002) or national banks (Scott Fulford 2015). While most agricultural states did not publish bank balance sheet data before 1900, bank directories throughout the period provided "a full and complete list of banks, bankers and savings banks in the United States" (Rand McNally Bankers Directory 1899, title page). We assemble a nation-wide bank database from 1870 to 1900 from the Merchants and Bankers' Directory and Rand McNally Bankers' Directory. These annual directories provide the location of every bank in operation, as well as, whether they were chartered by a state legislature (state bank, trust company, or savings bank) or the Comptroller of the Currency (national bank), and thus provide a measure of the size of banking in any given county. ${ }^{17}$

Following Rajan and Ramcharan (2011), we measure wealth inequality using the degree of land inequality among farm operators. Specifically, we calculate the Gini coefficient based on

\footnotetext{
${ }^{17}$ For the empirical analysis, we merge trust companies and savings banks with state banks because they were chartered in the same manner, took in deposits, and made most of their money from loans. The results are similar when we do not include trust companies.
} 
the distribution of farm sizes at the county-level provided by the census records compiled by Michael Haines (2004). ${ }^{18}$ The tabulated data contain the number of farms within seven acreage bins (less than 9 acres, 10 to 19 acres, 20 to 49 acres, 50 to 99 acres, 100 to 499 acres, 500 acres to 1,000 acres, and more than 1,000 acres), and we construct the estimate using the midpoint of acreage between the values in each bin. ${ }^{19}$ Taking a value between 0 and 1 , a large coefficient implies that a greater proportion of agricultural land was farmed by a few farm operators, whereas a low coefficient would imply uniformly small, medium, or large farms. A high Gini coefficient signals that a few individuals held a great deal of power, whereas a low coefficient implies that no small group of individuals had the power and self-interest to influence countylevel institutions.

There are two potential sources of measurement error in measuring inequality of wealth and land ownership with this particular measure of the inequality. First, farm size may not fully account for wealth or the power of local interest groups when land was used for mining, manufacturing, or residential. The evidence, at the very least, suggests that agriculture made up 68 percent of land in the average county and some of the remaining "land" was likely rivers, lakes, and other uninhabitable areas. Wealth not captured by the Gini thus would be limited and generally confined to large urban and manufacturing areas, especially for the South. This is one reason why we remove counties containing a city of more than 25,000 people from the regression analysis and control for manufacturing output. ${ }^{20}$

\footnotetext{
${ }^{18}$ Notice that an inequality measure is important because a landowner might only wish to prevent (or encourage) financial development when it gave him additional power over small farmers who were reliant upon credit. The incentives in a county with many large landowners and few small farms would be different from those in a county with one large landowner and many smaller farms. Therefore, the empirical results are weaker for measures such as the Herfindahl index or the fraction of large farms in a county.

${ }^{19}$ The 100 to 499 acre bin is divided into three separate bins in some decades. We aggregate the extra bins to create a consistent measure across time.

${ }^{20}$ The coefficients become more statistically significant when we exclude urban areas of 15,000 people or more.
} 
We test whether the farm size Gini is a good proxy for overall wealth inequality using the IPUMS 1 percent sample of the Census of 1870 (Ruggles et al. 2010). The 1870 Census was the last census to ask households about their wealth. Because there were often few sampled households per county in the IPUMS sample, we aggregated to the state level before calculating the Gini coefficient. ${ }^{21}$ The correlation between the wealth Gini and the farm operation size Gini across all states is 0.57 , but varies by region. It is 0.34 for the Northeast, 0.14 for the Midwest, 0.72 for the South, and 0.43 for the West. The farm size Gini thus seems to match the inequality of wealth for the South that was more agricultural better than in areas where there was relatively more non-land based wealth.

Second, farm sizes reported in the census are not perfectly matched with the size of agricultural landholdings. The census did not consistently report information on the amount of land owned by people. Instead, it reported information on the size of farms for farm operators, which included owner/operators, tenants (cash or share) and share croppers. For example, a plantation on which the landowner farms part of his acreage, rents to 3 cash tenants and 10 share tenants, and hires 20 share croppers would show up as 34 farm operations instead of 1 plantation with a single land owner. The distribution of farm size, therefore, only matches the distribution of agricultural landholdings in locations where landowners farmed all the land themselves, and otherwise underestimates the inequality of land holdings. We limit the impact of this type of measurement error by controlling for the fraction of tenant farms in the eventual regression analysis.

\footnotetext{
${ }^{21}$ When we use county or SEA data and drop observations with few sampled individuals, the correlations are slightly less but display a similar regional pattern. The bins are: no wealth, 1 to 50, 50-99, 100-199, 200-299, 300-399, 400499, 500-749, 750-999, 1,000-1,999, 2,000-2,999, 3,000-3,999, 4,000-4,999, 5,000-7,499, 7,500-9,999, 10,00014,999, 15,000-19,999, more than 200,000. The midpoint of each bin was used to calculate the Gini.
} 
We perform two tests to see how much the Gini for farm land holdings differs from the Gini for farm operations. The 1945 Agricultural Census was the first to publish detailed size distributions for multi-unit farm operations like plantations in the South (U.S. Census Bureau 1947). When only focusing on the exact distribution of the size of each owner's holdings rather than the distribution of tenant farms within those holdings, the correlation across counties between the Gini of all farm operations versus the Gini that treats each multi-unit operation as only one farm is 0.945 . When tenants are counted as being farmers with no land, the correlation becomes $0.8047 .{ }^{22}$ To see whether the structure of plantations did not change over time, we performed a second comparison using data on the size of owner operated farms in 1880 and 1890 (1870 and 1900 were unavailable). The correlation between the Gini for owner operators and the Gini for farm operation size is 0.91 . The ratio of the size of tenant and cropper farms to the size of owner-operator farms also remained relatively constant across the two decades. Therefore, to the extent that these relationships remained constant across the entire period, the Gini coefficient provides a reasonable proxy for the inequality of farm owners and county-fixed effects should control for much of the measurement error.

\section{Land Inequality and Financial Development Before 1900}

There was a great deal of variation in the Gini coefficient across locations and time.

Figure II shows that land in farm operations was more unequally distributed in the South and West than in the Northeast and Midwest. ${ }^{23}$ In the Midwest and Northeast, the inequality measure displayed relatively little variation, in contrast with the large degree of variation within the South and West. In fact, farm inequality in the South actually goes hand-in-hand with cotton

\footnotetext{
22 The correlation is only slightly lower in the South (0.8029) as it is for the entire country.

${ }^{23}$ The concentration of land holdings in the southwest is largely due to their small numbers of farms and large county boundaries, and might only compare a few family farms to large cattle ranchers.
} 
production. The Gini coefficient was higher in the cotton counties on either side of the Mississippi River and along the Atlantic coast, but lower for the non-cotton counties of Georgia and Tennessee. The finding suggests that variables such as soil quality, topography, and climate could have shaped the amount of inequality over time by altering the types of crops that could be farmed (Higgs 1977; Ransom and Sutch 1977).

Table I indicates that the inequality in the size of farm operations was rising in the South and Northeast and falling in the Midwest and West. Between 1860 and 1900, inequality rose by almost 2 percentage points in the Northeast and 2.4 percentage points in the South, but declined by 2.9 percentage points in the West and 7.4 percentage points in the Midwest. Despite the flood of former slaves released into the southern labor market, farm size inequality only slightly increased between 1860 and 1870 and had nearly returned to its original value by 1880 . This temporary increase was likely caused by time it took freedmen to become farm operators.

In order to properly observe the relationship between inequality and banks, we need to control for the large number of characteristics and institutions that could have been driving both factors. We, therefore, proceed with a regression analysis at the county-level aggregated up to their 1860 boundaries. To examine local conditions of interest groups in agricultural regions rather than relationships in areas where agriculture was not important, we drop any county that was larger than 7,000 square miles as well as those that had fewer than 20 farms or a city of 25,000 people or more. ${ }^{24}$ First, the square mile limit was imposed because the aggregation to counties based on 1860 boundaries creates a few large counties where it is inconceivable that a landowner or even a group of landowners would have had the power and self-interest to effect change over such as broad area. Moreover, the larger the county is the harder it is to get a proper

\footnotetext{
${ }^{24}$ We matched counties using information from Patrick Horan and Peggy Hargis (1995). Removing the cutoffs on farms or square miles decreases the precision of the estimates but the results remain. The results when keeping counties with a large city are shown in a later table, and the results are also similar when picking a lower cutoff.
} 
measure of inequality. For example, the effect of inequality of a region is very different if all the large landowners are competing in the same market versus spread out amongst many locations where they have no local competition. By dropping out the extremely large counties, we avoid this type of measurement error. The cutoff was chosen based on a relative break in the distribution county size and drops out about 1.5 percent of counties with most being located on the western frontier (for example California, Oregon, or Texas). Second, counties with few farmers are dropped because it is unlikely that farming in these counties was important to the local community. The cutoff was chosen to eliminate the lowest 1 percent of counties. Finally, urban areas in any year are dropped because they tended to focus on manufacturing and often had stock markets and other types of financial institutions. The cutoff was chosen because it is how the Census defines a large city. About 4.5 percent of counties were dropped, mostly in the manufacturing areas of the Northeast and eastern Midwest. The resulting panel contains information for $1870,1880,1890$, and 1900 for 1,564 counties in 38 states. $^{25}$

Following Rajan and Ramcharan (2011), we estimate a county's financial development over the period using a linear model. ${ }^{26}$ However, we take further steps in the analysis by pooling the data over time and using county fixed effects to control for time-invariant features for each county, year fixed effects to control for nation-wide shocks, and state by year fixed effects to control for state-specific shocks in each year. Each observation is a county-year. The dependent

\footnotetext{
${ }^{25}$ Excluded states were typically those that did not obtain statehood until after 1875 . The dropped states were Alaska, Hawaii, Oklahoma, South Dakota, North Dakota, Montana, Idaho, Utah, New Mexico, Arizona, Wyoming, and Washington. We do not use the 1860 observations for banks because of the largely exogenous destruction of banks due to the National Banking Acts and Civil War, but we do use non-financial variables in 1860 to control for other time-varying county-level characteristics because they did not experience a large change.

${ }^{26}$ Given many of the counties have no banks early in the sample, a Tobit regression that takes account of the censoring could also be used. We chose the linear model not only to match previous studies but also because the censored regressions do not generally work well in a panel context with many fixed-effects. We believe these fixed effects are vital to control for the many unobserved factors underlying geographic factors as well as those factors that are changing over the panel's long period.
} 
variable, Banks $s_{i, t}$, is the number of banks per thousand residents in county $i$ in year $t$ (called banks per capita). ${ }^{27}$ The full model is as follows:

$$
\text { Banks }_{i, t}=a+\beta_{1} \text { Gini }_{i, t-10}+\beta_{2} X_{i, t-10}+T+S * T+u_{i}+e_{i, t}(1)
$$

$X_{i, t-10}$ is the vector of time-varying county-level controls from the prior census year described below, $T$ is a vector of year fixed effects, $S$ is a vector of state fixed effects, $u_{i}$ denotes a vector of county-level fixed effects ${ }^{28}$, and $e_{i, t}$ is the error term. The vector of county fixed effects controls for features of the county, such as nearness to rivers, coast-lines, elevation, soil quality, type of agriculture, and other factors that did not change over time but varied across counties. The vector of year fixed effects controls for national-level shocks to the money supply and national legislation related to excise taxes and tariffs. The vector of state fixed effects interacted with the year fixed effects controls for differences in state policies over time. For instance, Sylla (1969) and James (1976) have argued that the lowering of state-specific and national minimum capital requirements increased the number of banks and decreased interest rate differentials across regions.

The key parameter estimated is $\beta_{1}$ the coefficient on the Gini measure from the previous census year $\left(G_{i n i} i_{i, t-10}\right)$. We measure the Gini during the previous census year to reduce problems with simultaneity and endogeneity. The models of Philippe Aghion and Patrick Bolton (1997), Abhijit Banerjee and Andrew Newman (1991), and Galor and Joseph Zeira (1993) indicate that economic inequality is shaped by credit availability. In our context, the Gini in year $t$ would likely have been influenced by Banks in year $t$, leading to a correlation with the error term $e_{i, t}$. The Ordinary Least Squares (OLS) estimation of $B a n k s_{i, t}$ on $G i n i_{i, t}$ thus would lead to

\footnotetext{
${ }^{27}$ While unreported, the results when using the number of banks are similar but provide more robust positive coefficients on the Gini coefficient. We thus have chosen to follow Rajan and Ramcharan's approach as it produces more conservative results.

${ }^{28}$ Results are similar when replacing the county fixed effects with state fixed effects and the large number of time invariant variables used in equation (2).
} 
a bias to the extent that increases in the financial development affected inequality. Because serial correlation in most economic series rarely extends beyond 5 years, it is not likely that the farm inequality Gini from ten years earlier would be correlated with the error term in year $t$ in the bank equation $\left(e_{i, t}\right)$.

We work to eliminate any additional endogeneity bias that might arise from the omission of variables that were correlated with both banks and farm inequality. First, we control for time varying county demographics. The demand for banking services is captured by the logarithm of population, and the impact of race on credit, social, and economic relationships is captured by the fraction of the county's population that was non-white. Second, we control for the economic environment. County production is measured as the logarithms of crop output per capita and manufacturing output per capita. The size of the agricultural sector is the logarithm of the number of farms. Because the presence of a bank has been shown to lead to future growth in output and population, we use the lagged values of the county-level variables to avoid simultaneity and endogeneity. The summary statistics of the main variables are presented in Table II.

On Table III, we present the results. The coefficients on the lagged Gini coefficient are positive but statistically insignificant for the entire country. Because agricultural wealth was not an important driver of institutions in many areas of the country, the estimates are not unexpected. We separately estimate the model for just the southern states to see if the effects differ because the stories of powerful landlords and merchants are centered on the South. For this region, the positive effect of the Gini is statistically significant and is twice the size as the effect for all states. The evidence thus indicates that inequality had its largest impact on banks in locations where the influence of agricultural interests would have been the largest. 
We report a number of additional specifications in Table IV to test whether the positive relationship between banks and land concentration is the result of choices about the sample and/or the inclusion of different sets or correlates. First, dropping counties with large cities helps us eliminate measurement error from locations with non-agricultural wealth and few farms. We, therefore, re-estimate equation (1) that includes large cities and adds a control for the fraction of people living in an urban area on the right hand side. When urban areas are included, the coefficient on the Gini in the first panel of Table IV decreases in value and losses its statistical significance in the South. The results provide additional evidence that including areas where agricultural interests played less of a role leads to a more negative relationship between farm inequality and banks that is statistically insignificant.

Using lagged values avoids the potential for auto-correlation with the error term, but also could be diluting the results. We, therefore, re-estimate equation (1) using contemporary values for all county-level variables to make sure that the results are robust to our chosen specification. ${ }^{29}$ In the second panel, the results using the county variables in the same year are roughly equivalent to those using lagged values in Table III, suggesting that the results are not driven by our choice of model specification.

We take the additional step of using an IV estimation procedure in case the use of lagged values for the Gini does not resolve the endogeneity problem. The IV is based on the average rainfall instrument used by Rajan and Ramcharan. The presence of county-fixed effects prevents us from using long-run rainfall as the instrument and the lack of sufficient weather stations before 1896 prevents us from using rainfall per decade. In the third panel we interact the long run average rainfall for 1896 to 1930 with a dummy for 1880,1890 , and 1900 to allow for variations

\footnotetext{
${ }^{29}$ While its inclusion does not dramatically alter the results, we continue to exclude observations in 1860 in order to avoid changes due to the Civil War and National Banking Acts.
} 
in the effect of the rainfall on the Gini in each of the four years. Though the IV estimates likely suffer from weak instrument bias with F-statistics of 3.77 and 5.49, the IV approach produces significantly larger coefficients than those in the OLS model. In this case, the coefficient on the Gini is positive and statistically significant for the entire nation as well as the South.

The fourth and fifth specifications are separate models with the number of state banks per thousand people and the number of national banks per thousand as dependent variables. ${ }^{30}$ As national banks could not provide loans on real estate directly, they would have served a different purpose in agricultural regions than state banks and would not have competed with large landowners in the provision of farm mortgage loans; therefore, the relationship between the number of banks and inequality could have been different for the two types of banks. The overall results show a positive relationship between inequality and the number of banks of any kind. While the coefficients are always positive, the relationship with inequality is only statistically significant for national banks in the South.

The final specification examines the effect of the Gini coefficient on the number of private bankers per thousand people. As previously highlighted, private bankers were unincorporated and generally were not subject to state or national regulations. They typically had little to no formal capital stock and only provided short-term consumption loans to farmers. We have not included these institutions in prior specifications because we wanted to focus on incorporated commercial banks as did Rajan and Ramcharan for 1920 and 1930. However, analyzing the relationship between private bankers and the Gini coefficient gives a sense of how land concentration affected the unincorporated banking sector. While statistically insignificant, the negative coefficients suggest a different relationship between the Gini and the number of private

\footnotetext{
${ }^{30} \mathrm{We}$ include the number of trust companies in the count of the number of state banks because they were chartered in the same way and carried out similar actions.
} 
bankers from the ones for either national or state banks. ${ }^{31}$ Land concentration, therefore, may have led to more incorporated banks and fewer unincorporated ones. Areas with high land concentration seem to have had commercial banks whereas those with low concentration relied more on private bankers.

\section{Why Do Our Results Conflict with Rajan and Ramcharam's Results for 1920 and 1930}

The positive relationship between banking and farm operation inequality in the late $19^{\text {th }}$ century contrasts with the negative relationship found by Rajan and Ramcharan (2011) for1920 and 1930. There are two non-mutually exclusive reasons why the results in our paper differ from theirs: time period and identification strategy.

There was a substantial transformation of the financial system between 1870 and 1920 . The rural banking system was essentially starting from scratch after the Civil War and the National Banking Acts, and the commercial banking structure was significantly more mature in 1920. As seen in Figure III, only 32 percent of counties had at least one bank in 1870, yet over 95 percent of counties had at least one bank by 1910 and most had multiple banks competing for business. Many of these new banks were owned by former private bankers who had operated in areas without commercial banks (Barnett 1911). Towards the end of the 1880s and more strongly after 1900, states explicitly attempted to stamp out private bankers by preventing them from using the word "bank" in the name as well as making them subject to state supervision and minimum capital requirements. Thus, after 1900 banks were often competing against other banks for business within the same county.

\footnotetext{
${ }^{31}$ The lack of statistical significance is not surprising. Barnett (1911) indicates that private bankers in agricultural regions were relatively slow growing before 1900. Specifically, a large portion of the growth in total private bankers was in financial centers such as Chicago and New York City where they did brokerage business. As such, most of the private bankers are going to be strongly correlated with the county-fixed effects when we drop out urban centers.
} 
The competition for agricultural loans intensified when the federal government provided startup money for Federal Land Banks and joint stock banks after 1916. Both types of banks were created to provide funding for low interest loans to farmers. ${ }^{32}$ Moreover, the creation of the Federal Reserve in 1914 lowered liquidity risk as it allowed member banks to borrow at the discount window to meet seasonal demand, and non-member banks often received seasonal funds indirectly through their correspondents (Calomiris, Jaremski, Park and Richardson 2016). By the 1920s, the financial sector was much more like that of the retailing and industrial sectors where incumbents often battled against entry by new stores. This view is consistent with Rajan and Ramcharan's (2016) argument that after the Great Contraction from 1929-1933 surviving banks were able to prevent new banks from rising up to take the place of those that closed.

Farmers and farm workers in the 1920s also had higher incomes and greater flexibility than those in the late $19^{\text {th }}$ century. For instance, 31 percent of farms had automobiles in 1920 . By 1930, 58 percent of farms, 86 percent of farm owners and 48 percent of farm tenants reported having automobiles and over 34 percent of all households reported having telephones (U.S. Census Bureau 1922, pp. 22; 1933, pp. 535; 1943, pp. 451-454). ${ }^{33}$ Farmers, therefore, had greater capacity to go outside their community for loans, creating more cross-county competition among banks. Admittedly, this effect was probably strongest in locations where towns were clustered or in suburbs of large cities. Increased competition led to more integration of lending markets. While at a higher level of aggregation, Bodenhorn's (1996) estimates show that the

\footnotetext{
${ }^{32}$ The Federal Government provided seed money and federal backing of the issuance of securities for a set of regional Land Banks that worked with local farm associations to develop cooperative mortgage lending. The government also created the structure for joint stock banks funded by farmers directly. By 1930, the share of mortgages held by federal land banks was over 12 percent and the share held by joint stock banks was about 6 percent (Federal Farm Loan Board 1931, pp. 14-15, 31). In addition, the federal government provided emergency loans through Congressional legislation to areas hit by disaster on at least 5 occasions during the 1920 s, giving poor farmers a safety net when climbing the agricultural ladder.

${ }^{33}$ The numbers are slightly lower in the South, but still non-trivial: 54 percent of farm owners and 31 percent of farm tenants owned automobiles.
} 
standard deviation across states in commercial bank interest rates fell from an average of about 5 percentage points in the late 1870 s to around 2.7 in the 1890 s to around 1 percentage point in the 1920s.

The difference between the two studies could also be based on different identification strategies. Our panel analysis identifies the effect of the Gini coefficient based on variation over time within a county while controlling for state-wide shocks in each year. In contrast, the identification in Rajan and Ramcharam's analysis comes from variation across counties within the same state in the same year. The panel process allows us a longer timespan to better control for omitted variable bias, whereas the Rajan and Ramcharan use an IV in order to reduce endogeneity and measurement error.

To sort out the reasons why the results differ, we have to determine whether the crosssectional regressions tend to provide negative results in all periods and whether the additional panel controls lead to a different result in the 1900s. Adding data for 1910, 1920, and 1930, we conduct this analysis in two steps. We first examine decade cross-sections to see if the difference has to do with the additional controls and identification of the panel. We then re-estimate the panel regressions using additional years but holding the specification fixed in order to see if the changing time-span is responsible.

We present the regression estimates in Table V where we apply Rajan and Ramcharam's cross-sectional approach for each decade from 1870 through 1930. Lacking time-series variation, the model is:

$$
\operatorname{Banks}_{i}=a+\beta_{1} \operatorname{Gini}_{i}+\beta_{2} X_{i}+S+e_{i}(2)
$$

the variables retain the previous definitions with the exception of $X_{i}$. Because the specifications cannot include county-fixed effects, we include a variety of constant county-level characteristics 
that could be driving the number of banks in $X_{i}$ : the fraction of the population that was illiterate, the fraction of the population that was aged 8 through 20 , and the fraction of farms that are worked by a tenant. ${ }^{34}$ The fraction of tenant farms is particularly important to control for any mismeasurement of the Gini in locations with high shares of tenant and cropper farms. As small family farms often did not generate sufficient surplus to avoid foreclosure during bad periods, we would expect locations with low rainfall and extreme temperatures to naturally have a higher concentration of acres in large farms that could withstand shocks. Due to the lack of early weather stations, we use average rainfall, average temperature, and the standard deviation of temperature from 1895 through $1930 .{ }^{35}$ As a rugged landscape, lack of water, and bad soil would limit agriculture, we control for the difference between the highest and lowest elevations in a county, the amount of moisture in the soil, the percent of clay in the soil, and whether the county had a large river or coast within its borders. ${ }^{36}$

Rajan and Ramcharan's original models do not include all of these control variables. Therefore, to offer a clear comparison to their results, we estimate a regression as close to their specification as possible and then slowly add controls. We start with a model similar to theirs that only contains population, land area, whether the county was on a large river or coast, fraction illiterate, fraction young, fraction non-white, and state-fixed effects. ${ }^{37}$ Next we add the

\footnotetext{
${ }^{34}$ Because the Census did not consistently measure or report these three variables, we thus take the maximum value of the county for all years when they are reported.

${ }^{35}$ There is a large literature on the connection between land concentration and weather patterns. See for instance, Early Heady (1952), Thomas Tomich et. al (1995), and Bruce Gardner (2002). We find that the climate measures were relatively consistent decade to decade. The measures thus seem to provide a good proxy for the county's general suitability to growing crops and potential risk of extreme weather.

${ }^{36}$ The geographic variables were created by Fishback, Haines, and Shawn Kantor (2006). The paper describes the sources. More can be downloaded from http://www.u.arizona.edu/ fishback/Published_Research_Datasets.html.

${ }^{37}$ When we run the Rajan and Ramcharan's specification, there are some differences in variables used as correlates, but we see no sign that the differences influence the statistical significance of the inequality measure. In the geographic measures Rajan and Ramcharan use distance from the Mississippi River, the Great Lakes, and Oceans. We use dummy variables to show whether a county is located along rivers of different sizes and/or is adjacent to oceans and the Great Lakes. Further we drop the urbanization variable and replace it with population as we drop out all large urban areas before estimation.
} 
additional Census, weather, and topological controls listed above. Finally we follow Rajan and Ramcharan and use long-term rainfall as an instrument instead of a control.

The identification of the impact of the Gini in Table $\mathrm{V}$ comes from variation across counties within the same state. Looking across the entire nation, the OLS results in 1920 and 1930 are similar to the ones Rajan and Ramcharan (2016) report in their online Data Appendix. In both years the OLS coefficients for the Gini are negative and statistically significant. As we move earlier in time, however, the negative effect of the Gini becomes less stable, particularly when the additional controls are added. For instance, the coefficients in the OLS model with additional controls are not statistically significant in 1880, 1900, and 1910.

In general, the IV strategy leads to a much stronger negative and significant effect of the Gini coefficient on banks than the OLS estimates. Indeed, the negative relationship is only statistically insignificant in 1870. It is not clear, however, that long run rainfall is a good instrument in this context. The problem is not with strength, as the F-statistics for the instrument in the first stage are over 30 in all years except for 1870, when it is 5.2. The problem is with rainfall's excludability: Can we legitimately expect that long run average rainfall is uncorrelated with the error term? In agricultural areas, access to rainfall is a major consideration in determining the economic opportunities; therefore, the people considering organizing a bank were likely to consider long run rainfall patterns when choosing to enter or exit the county. This would be true even while controlling for current or past income in the equation because long run rainfall covers a much longer time span than just the current year. Whether the current year income was low or high, the long run rainfall average provides additional information about whether the current year income was a good, bad, or average year. Thus, we might expect that the rainfall measure would belong in the final stage equation as a correlate. In fact, in the OLS 
cross-sectional analysis with long run rainfall included as an additional correlate for banks per capita, the rainfall coefficient is negative and statistically significant in every year from 1870 to 1920. The only year in which it is not statistically significant is 1930 .

As before, we estimate the cross-sectional models using only counties in the South and find much less negative results. The negative coefficients on the Gini are never statistically significant for southern counties when we include the full set of controls. Moreover, the coefficients from IV regressions are generally smaller in magnitude and are not statistically significant in $1870,1890,1900$, and 1930 . The F-statistics suggest that rainfall is not a very powerful instrument of the Gini coefficient in the South until the 1900s.

The cross-sectional results suggest three conclusions. First, the differences in identification strategies lead to different results. Negative coefficients are present when the identification comes from cross-county variation within states, positive coefficients are more common when using variation across time within counties controlling for annual shocks within states. Second, the changing nature of the financial infrastructure also seems to be a factor. Specifically, the negative coefficients on the Gini are larger and more consistently significant after 1900. Third, the mix of agriculture and manufacturing areas in the nation-wide sample biases the results downwards. When focusing on the South and controlling for additional county characteristics, the negative effect of the Gini is never statistically significant.

We next test whether the panel structure also picks up this change in the effect of the Gini coefficient. To do this, we extend our panel analysis through additional years. Specifically, we examine the results when adding additional data for 1910,1920 , and $1930 .^{38}$ The first panel of

\footnotetext{
${ }^{38}$ Data from 1910 comes from the same Rand McNally Bankers Directory, whereas the later data come from the Federal Deposit Insurance Corporation (2001). Additional panel specifications for other sets of years are available upon request. However, the results are similar with the Gini mattering more early and mattering less after 1900. We
} 
Table VI shows the results when estimating equation (1) using just 1870 through 1890 . Then each subsequent panel adds another decade. Like Rajan and Ramcharam, we control for differences in state regulation of capital, reserve requirements, usury rates, and bank supervision which in the panel context means including state-by-year fixed effects.

In the panels for different time periods, the positive effects of the Gini coefficient are largest for the 1870-1890 and 1870-1900 periods when there were relatively few banks. The coefficients get smaller as more years are added to the panel. The coefficient on the Gini coefficient is even statistically significant and positive for the entire country from 1870 through 1890. The coefficients for the full country become insignificant when 1900 is added to the panel, turn insignificant negative when 1910 is added, and become negative and significant when 1920 is added to the sample. The results for the South sample show roughly the same pattern but with less negative coefficients. There are statistically significant positive coefficients in the panels for 1870-1890 and 1870-1900, while adding any year after 1900 leads to negative but statistically insignificant coefficients.

The comparisons of the panels suggest that there was a change in the relationship between banks and the Gini sometime after 1900. At the bottom of Table VI are the panel results for the periods 1900-1930 and 1910-1930. The coefficients on the Gini are all negative although none are statistically significant. The changing nature of the financial system and regulation seem to be leading to a differential effect between the two time periods. Given that it is a change based on time period, it seems likely that the change would be a national one. One candidate for such a change was the new lower capital requirements in small communities for national banks enacted with the Gold Standard Act of 1900. The Act lowered the minimum capital requirement

do not implement the IV approach for the panel as long-run rainfall has already been shown to be a poor instrument when accounting for county-fixed effects and state by year fixed effects. 
for locations with fewer than 4,000 people to only $\$ 25,000$. The number of national banks grew rapidly over the next decade. Of the 3,387 national banks created between 1899 and 1909, 2,197 or 65 percent had a capital stock lower than $\$ 50,000$ (Barnett 1911, pp. 232-233). Even as some state banks converted to a national charter, state bank growth kept pace with national banks as states further lowered their capital requirements. In particular, much of this state bank growth was driven by private bankers taking out formal bank charters as a result of new state regulations. The number of private bankers fell from around 4,300 in 1900 to less than 600 in 1930. ${ }^{39}$ As such, the size of banks decreased over time and more areas were able to create multiple competing banks. Since most counties had a bank by 1900 , it would not be a surprise that the banking elite sought to block entry, just as would be the case of any type of firm.

\section{Conclusion}

This paper examines the extent to which landed elites affected the development of commercial banking in rural areas following the Civil War from 1870 through 1900 . The National Banking Acts during the Civil War forced the commercial banking system in agricultural areas to start anew, as a result of tighter regulations on both national and state banks. We thus examine a period near the height of landowner power, informal farm credit, and during the rebirth of agricultural finance. We find that areas with a higher concentration of farming in larger farm operations, tended to establish more banks.

The results for 1870 to 1900 differ from the findings of a negative relationship between banks and inequality by Rajan and Ramcharan (2011) for 1920 and 1930. We believe that there are two reasons for such a difference: a difference in the method of identification and a

\footnotetext{
${ }^{39}$ When we include private bankers in the panel analysis, we find similar but smaller positive effects of the Gini coefficient on banks. These estimates are available upon request.
} 
substantial change in the structure of banking. Rajan and Ramcharam's identification came from cross-sectional variation across counties within the same state, as well as the use of long run rainfall as an instrument for inequality. When we use Rajan and Ramcharam's identification methods for the late 1800 s, the banking-inequality relationship in the cross-section is often negative, as they found for 1920 and 1930. However, there are economic reasons to question the validity of the rainfall measure as an instrument as long run rainfall is likely an important consideration for the decision to open a bank and likely belongs as a correlated in the final stage bank equation. In fact, it has a statistically significant effect when included alongside the Gini coefficient in the final banking equation. Our identification method is based on variation across time within counties while controlling for state-year specific differences. Using our panel identification methods, we find that there is no longer a positive relationship between banking and inequality after 1900 in most specifications.

There are a variety of reasons why the banking structure in the U.S. differed substantially between the late 1800 s and the 1920s. Nearly every county had a bank by 1910 and most counties had multiple banks. Moreover, the federal government had sharply reduced minimum capital requirements for national banks in small communities with the Gold Standard Act of 1900. The government even began to provide start-up funding for national land banks that made loans to mutual associations of farmers and the Federal Reserve was created to provide seasonal liquidity to banks. Most states had also begun to force private bankers that were operating without a charter into the formal banking sector or out of the market. Banking markets thus were much more integrated and had government support after 1900.

The new results thus tell a more complex story about the relationship between inequality and financial development. When rural and agricultural areas started from scratch after the Civil 
War and the National Banking Acts, the elites in those areas, composed primarily of large landowners, joined forces to invest in local banks to expand credit and the breadth of development beyond agriculture in the late 1800s. As the formal credit markets matured and interest rate differentials declined, the relationship was weakened and farm operation inequality began to negatively affect banks. As part owners of the banks, landed elites had an incentive to prevent entry, just as retailers and other local businesses had incentives to prevent entry, particularly from expanding chain stores (Rajan and Ramcharan 2016). It, however, was not until the early 1900s when population and regulation had reached a point where most counties had banks and thus had incumbent banks who would seek to prevent entry by new banks. Thus, the opposition to additional banks in rural areas found by Rajan and Ramcharan was more likely to have been driven by local elites protecting banks rather than protection of informal consumption credit that banks rarely ever provided. 


\section{Works Cited}

Acemoglu, D., and J.A. Robinson. Why Nations Fail: The Origins of Power, Prosperity, and Poverty. New York: Crown Business, 2012.

Aghion, Philippe, and Patrick Bolton. "A theory of trickle-down growth and development". Review of Economic Studies 64 (1997): 151-172.

Banerjee, Abhijit V., and Andrew F. Newman. "Risk-bearing and the theory of income distribution". Review of Economic Studies 58 (1991): 211-235.

Barnett, George. State Banks and Trust Companies since the Passage of the National-Bank Act. Washington: Government Printing Office, 1911.

Bodenhorn Howard. "A More Perfect Union: Regional Interest Rates in the Twentieth Century United States." In Anglo-American Financial Systems edited by M. Bordo and R. Sylla, 415-53. Burr Ridge, Illinois: Irwin, 1996. Data downloaded from http://people.clemson.edu/ bodnhrn/data.html on 8/23/2013.

Bodenhorn, Howard and David Cuberes. "Financial Development and City Growth: Evidence From Northeastern American Cities, 1790-1870." NBER Working Paper 15997, 2010.

Bogue, Allan G. Money at interest: The farm mortgage on the middle border. Ithaca, NY: Cornell University Press, 1955.

Board of Governors of the Federal Reserve System. All-Bank Statistics, United States, 18961955. Washington: Board of Governors, 1959.

Calomiris, Charles, and Carlos Ramirez. "The political economy of bank entry restrictions: Theory and evidence from the U.S. in the 1920s". Working paper, Columbia University, 2004.

Calomiris, Charles, Matthew Jaremski, Haelim Park, et al. "Liquidity Risk, Bank Networks, and the Value of Joining the Fed". NBER Working Paper w21684, 2015.

Carlson, Mark and Kris James Mitchener. "Branch Banking, Bank Competition and Financial Stability." Journal of Money Credit and Banking 38 (2006): 1293-1328.

Carter, Susan, Sigmund Carter, Haines Scott, et al. Historical Statistics of the United States: Earliest Times to the Present, Millennial Edition. New York: Cambridge University Press, 2006.

Coquillette, Calvin. "The Struggle to Preserve Iowa's State Banking System, 1920-1933." The Annals of Iowa 60 (2001): 35-59.

Daniel, Pete. The Shadow of Slavery: Peonage in the South, 1901-1969. New York: Oxford University Press, 1973.

Davis, Lance. "The investment market, 1870-1914: The evolution of a national market". Journal of Economic History 25 (1965), 355-399.

Dehejia, Rajeev and Adriana Lleras-Muney. "Institutions, Financial Development, and Pathways of Growth: The United States from 1900 to 1940". Journal of Law and Economics 50 (2007): 239-272.

Eichengreen, Barry. "Mortgage Rates in the Populist Era." American Economic Review 74 (1984): 995-1015.

"Agricultural Mortgages in the Populist Era: Reply to Snowden." Journal of Economic History 47 (1987): 757-760.

Engerman, S., E. Mariscal, and K. Sokoloff. "The Evolution of Schooling Institutions in the Americas, 1800-1925”. UCLA Working Paper, 2002.

Engerman, Stanley, and Kenneth Sokoloff. "Factor endowments, inequality, and paths of development among new world economies". Economía 3 (2002): 41-109. 
Federal Deposit Insurance Corporation. "Federal Deposit insurance Corporation Data on Banks in the United States, 1920-1936. ICPSR ed. Ann Arbor, MI: Inter-university Consortium for Political and Social Research, 2001.

Federal Farm Board. Fourteenth Annual Report of the Federal Farm Board for the Year Ending December 31, 1930. Washington, D.C.: Government Printing Office, 1931.

Fishback, Price. "Debt Peonage in Postbellum Georgia," Explorations in Economic History 26 (1989): 219-236.

Fishback, Price, Michael Haines, and Shawn Kantor.. "The Impact of New Deal Expenditures on Mobility During the Great Depression.” Explorations in Economic History 43 (2006): 179222.

FitzRandolph, Peter. "The Rural Furnishing Merchant in the Postbellum United States: A Study in Spatial Economics. Dissertation Summary." The Journal of Economic History 41 (1981): 187-188.

Fulford, Scott. "How important are banks for development? National banks in the United States 1870--1900". Review of Economics and Statistics 97 (2015): 921-938.

Galor, Oded and J. Zeira. "Income distribution and macroeconomics". Review of Economic Studies 60 (1993): 35-52.

Galor, Oded, Omer Moav, and Dietrich Vollrath. "Inequality in land ownership, the emergence of human capital promoting institutions, and the Great Divergence". Review of Economic Studies 76 (2009): 143-179.

Gardner, Bruce. American Agriculture in the Twentieth Century: How it Flourished and What it Costs. Harvard: Harvard University Press, 2002.

Goldin, Claudia. "“N' Kinds of Freedom: an Introduction to Issues." Explorations in Economic History 16 (1979): 8-30.

Greenwood, Jeremy and Boyan Jovanovic. "Financial development, growth, and the distribution of income". Journal of Political Economy 98 (1990): 1076-1107.

Gropp, Reint, John Scholz, and Michelle White. "Personal bankruptcy and credit supply and demand", Quarterly Journal of Economics 112 (1997): 217-251.

Haines, Michael R. Historical, Demographic, Economic, and Social Data: The United States, 1790-2000. ICPSR Study 2896. Ann Arbor, MI: Inter-university Consortium for Political and Social Research, 2004.

Hammond, M.B. "The Cotton Industry. An Essay in American Economic History: Part I. The Cotton Culture and Cotton Trade." Publications of the American Economic Association New Series 1 (1897): 3-382.

Haney, Lewis. "Farm Credit Conditions in a Cotton State". American Economic Review 4 ) 1914): 47-67.

Heady, Early O. Economics of Agricultural Production and Resource Use. New York: Prentice Hall, 1952.

Hicks, John D. Populist Revolt: A History of the Farmers' Alliance and the People's Party. Minneapolis: University of Minnesota Press, 1931.

Higgs, Robert. Competition and Coercion: Blacks in the American Economy, 1865-1914. New York: Cambridge University Press, 1977.

Holmes, George K. and John S. Lord. Report on Real Estate Mortgages in the United States at the Eleventh Census, 1890. Washington, D.C.: Government Printing Office, 1895. 
Horan, Patrick M., and Peggy G. Hargis. County Longitudinal Template, 1840-1990. ICPSR06576-v1. Ann Arbor, MI: Inter-university Consortium for Political and Social Research, 1995.

James, John. "Banking market structure, risk, and the pattern of local interest rates in the United States, 1893-1911". Review of Economics and Statistics 58 (1976a): 453-462. " "The Development of the National Money Market: 1893-1911". Journal of Economic History 36 (1976b): 878-897.

Jaremski, Matthew. "State Banks and the National Banking Acts: Measuring the Response to Increased Financial Regulation, 1860-1868”. Journal of Money, Credit, and Banking 45 (2013): 379-399

Jaremski, Matthew and Peter Rousseau. "Banks, Free Banks, and U.S. Economic Growth" Economic Inquiry 51 (2013): 1603-1621.

"The Dawn of an 'Age of Deposits' in the United States" NBER Working Paper No. 21503, 2015.

Keehn, Richard and Gene Smiley. "Mortgage Lending by National Banks". Business History Review 51 (1977): 474-491.

Lamoureaux, Naomi. Insider Lending: Banks, Personal Connections, and Economic Development in Industrial New England. New York: Cambridge University Press, 1996.

Lee, Virgil. Principles of Agricultural Credit. New York: McGraw-Hill Book Company, 1930.

Marler, Scott. "Two Kinds of Freedom: Mercantile Development and Labor Systems in Louisiana Cotton and Sugar Parishes After the Civil War.” Agricultural History 85 (2011): 225-251.

McGuire, Robert and Robert Higgs. "Cotton, Corn, and Risk in the Nineteenth Century: Another View.” Explorations in Economic History 14 (1977): 167-182.

Minnesota Population Center. National Historical Geographic Information System: Pre-release Version 0.1. Minneapolis, MN: University of Minnesota, 2004. http://www.nhgis.org.

Morman, James B. Farm Credits in the United States and Canada. New York: The Macmillan Company, 1924.

North, Douglas, John Wallis, and Barry Weingast. Violence and Social Orders: A Conceptual Framework for Interpreting Recorded Human History. New York: Cambridge University Press, 2009.

Officer, Lawrence. What Was the Value of the US Consumer Bundle Then? MeasuringWorth, 2008. http://www.measuringworth.org/consumer/

Rajan, Raghuram G. and Rodney Ramcharan. "Land and Credit: A Study of the Political Economy of Banking in the United States in the Early 20th Century." Journal of Finance 66 (2011): 1895-1931.

. "Crises and the Development of Economic Institutions: Some Microeconomic Evidence." American Economic Review 106 (2016): 524-27.

Ransom, Roger and Richard Sutch. "Debt peonage in the cotton south after the civil war." Journal of Economic History 32 (1972): 641-669. Once Kind of Freedom: The Economic Consequences of Emancipation. New York: Cambridge University Press, 1977.

Redenius, Scott. Between Reforms: The U.S. Banking System in the Postbellum Period. Ph.D. diss. Yale University, 2002. 
Rosenbloom, Joshua and William Sundstrom. "The Decline and Rise in Interstate Migration in the United States: Evidence from the IPUMS, 1850-1990.” Research in Economic History 22 (2004): 287-324.

Ruggles, Steven, J. Trent Alexander, Katie Genadek, et al. Integrated Public Use Microdata Series: Version 5.0. Minneapolis: University of Minnesota, 2010.

Schweikart, Larry. Banking in the American South from the Age of Jackson to Reconstruction. Baton Rouge, LA: LSU Press, 1987.

Snowden, Kenneth. "Mortgage Rates and American Capital Market Development in the Late Nineteenth Century.” Journal of Economic History 47 (1987): 671-691.

."The Evolution of Interregional Mortgage Lending, 1870-1940: The Life InsuranceMortgage Company Connection," in Coordination and Information: Historical Perspectives on the Organization of Enterprise edited by N. Lamoreaux and D. Raff, 209-47. Chicago: Univ. of Chicago, 1995.

Sylla, Richard. "Federal policy, banking market structure and capital mobilization in the United States, 1863-1913". Journal of Economic History 29 (1969): 675-686.

. The American Capital Market, 1846-1914: A study of the effects of public policy on economic development. New York: Arno Press, 1975.

Temin, Peter. "Freedom and Coercion: Notes on the Analysis of Debt Peonage in Once Kind of Freedom." Explorations in Economic History 16 (1979): 56-63.

Tomich, Thomas, Peter Kilby, and Bruce F. Johnston. Transforming Agrarian Economies. Ithaca, NY: Cornell University Press, 1995.

U.S. Census Bureau. Fourteenth Census of the United States: 1920. Volume IV, Part I, Agriculture. Washington, D.C.: Government Printing Office, 1922.

. Fifteenth Census of the United States: 1930. Volume IV, General Report. Washington, D.C.: Government Printing Office, 1933. Sixteenth Census of the United States: 1940. Agriculture, Volume III. General Report. Statistics by Subject. Washington, D.C.: Government Printing Office, 1943. . United States Census of Agriculture: 1945, Special Report of Multiple-Unit Operations in Selected Areas of Southern States. Washington, D.C.: Government Printing Office, 1947.

Weiner, Jonathan. "Planter-Merchant Conflict in Reconstruction Alabama". Past and Present 68 (1975): 73-94.

White, Eugene. “The Political Economy of Banking Regulation, 1864-1933.” Journal of Economic History 42 (1982): 30-40.

Woodman, Harold. King Cotton and His Retainers: Financing and Marketing the Cotton Crop of the South, 1800-1925. New York: Beard Books, 1999. Reprint of 1968 edition.

Wright, Gavin. Old South, New South: Revolutions in the Southern Economy since the Civil War. New York: Basic Books, Inc, 1986. 
Table I: Trends in Land Concentration By Region (1860-1900)

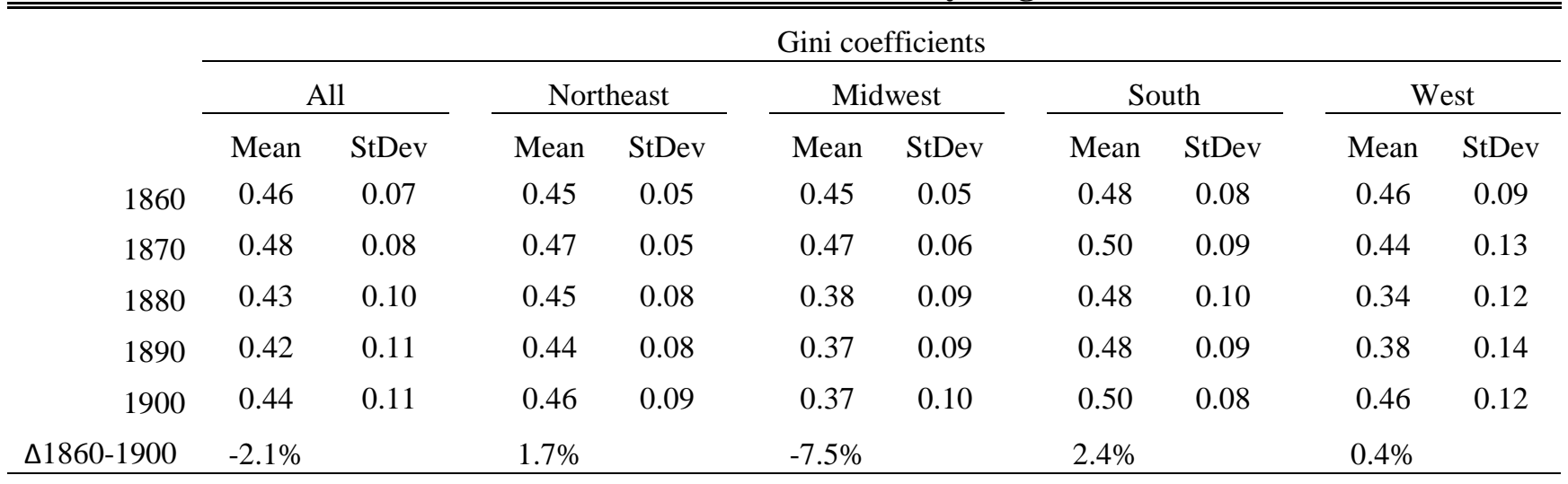

Notes: Table presents the average Gini coefficient of each region in each year. See text for data sources. 
Table II: Summary Statistics for 1870, 1880, 1890, and 1900

\begin{tabular}{lcc}
\hline \hline & Mean & Std Deviation \\
Fraction of counties with no banks & 0.433768 & 0.495634 \\
Fraction of counties with 1 bank & 0.164494 & 0.370753 \\
Fraction of counties with 2 banks & 0.121358 & 0.32657 \\
Fraction of counties with 3 banks & 0.076936 & 0.266511 \\
Number of banks per 1,000 people & 0.076785 & 0.105819 \\
Gini coefficient & 0.447106 & 0.094897 \\
Fraction non-white & 0.153442 & 0.21536 \\
Ln(county population) & 9.726913 & 0.781109 \\
Ln(mfg. output p.c.) & 48.65331 & 72.33183 \\
Ln(Crop output p.c.) & 60.67244 & 34.12759 \\
Ln(\# of farms) & 7.363458 & 0.87538 \\
\hline presents the summary statistics of the county-level panel used in panel regressions from 1870 through
\end{tabular}


Table III : Regression Estimates Explaining Number of Banks Per 1,000 People with a Panel for 1870, 1880, 1890, and 1900

\begin{tabular}{lccccc}
\hline & \multicolumn{2}{c}{ All states } & & \multicolumn{2}{c}{ South } \\
\cline { 2 - 3 } \cline { 5 - 6 } L.gini coeff & $(1)$ & $(2)$ & & $(3)$ & $(4)$ \\
& 0.011 & 0.021 & & $0.029 *$ & $0.042^{*} *$ \\
Location fixed effects & {$[0.015]$} & {$[0.018]$} & & {$[0.016]$} & {$[0.021]$} \\
Time fixed effects & State & County & & State & County \\
State-yr interactions & Yes & Yes & & Yes & Yes \\
Census controls & Yes & Yes & & Yes & Yes \\
Observations & Yes & Yes & & Yes & Yes \\
R-squared & 6,017 & 6,017 & & 2,703 & 2,703 \\
\hline
\end{tabular}

$*$ denotes significance at $10 \% ; * *$ at $5 \%$ level and $* * *$ at $1 \%$ level.

Notes: The table presents individual linear regressions. The dependent variable is the number of banks per 1,000 people. Panel formed by aggregating counties to boundaries in 1860 . Based on the Census designations, the South region defined by Alabama, Arkansas, Delaware, Florida, Georgia, Kentucky, Louisiana, Maryland, Mississippi, North and South Carolina, Oklahoma, Tennessee, Texas, Virginia, and West Virginia. County-level lagged variables: In(population), fraction nonwhite, $\ln$ (manufacturing output per capita), $\ln$ (agricultural output per capita), $\ln$ (\# of farms). Counties with more than 7,000 square miles, fewer than 20 farms, or any city of 25,000 or more are dropped. Dollar values are deflated to 1860 using Lawrence Officer (2008). Robust standard are provided in brackets. $*$ denotes significance at $10 \% ; * *$ at $5 \%$ level and $* * *$ at $1 \%$ level. 
Table IV: Impact of Farm Inequality on the Number of Banks Per 1,000 People with Alternative Specifications and Samples

\begin{tabular}{|c|c|c|}
\hline & \multicolumn{2}{|c|}{$\begin{array}{l}\text { Not dropping counties with city of } 25,000+\text { and } \\
\text { adding \%urban }\end{array}$} \\
\hline $\begin{array}{c}\text { L.gini coeff } \\
\text { Location fixed effects }\end{array}$ & $\begin{array}{c}\text { All } \\
-0.007 \\
{[0.017]} \\
\text { County }\end{array}$ & $\begin{array}{c}\text { South } \\
0.022 \\
{[0.020]} \\
\text { County }\end{array}$ \\
\hline & \multicolumn{2}{|c|}{$\begin{array}{c}\text { Contemporary values for } 1870,1880,1890 \text {, and } \\
1900\end{array}$} \\
\hline $\begin{array}{c}\text { Gini coeff } \\
\text { Location fixed effects }\end{array}$ & $\begin{array}{c}\text { All } \\
0.009 \\
{[0.018]} \\
\text { County }\end{array}$ & $\begin{array}{c}\text { South } \\
0.056^{* * *} \\
{[0.016]} \\
\text { County }\end{array}$ \\
\hline & \multicolumn{2}{|c|}{ IV using long-run rainfall x year } \\
\hline $\begin{array}{c}\text { L.gini coeff } \\
\text { Location fixed effects } \\
\text { F-stat on IV }\end{array}$ & $\begin{array}{c}\text { All } \\
1.603 * * * \\
{[0.563]} \\
\text { County } \\
3.77\end{array}$ & $\begin{array}{c}\text { South } \\
0.305^{*} \\
{[0.168]} \\
\text { County } \\
5.488\end{array}$ \\
\hline $\begin{array}{c}\text { L.gini coeff } \\
\text { Location fixed effects }\end{array}$ & $\begin{array}{c}\text { All } \\
0.008 \\
{[0.010]} \\
\text { County }\end{array}$ & $\begin{array}{c}\text { ly } \\
\text { South } \\
0.026^{*} \\
{[0.016]} \\
\text { County }\end{array}$ \\
\hline $\begin{array}{c}\text { L.gini coeff } \\
\text { Location fixed effects }\end{array}$ & $\begin{array}{c}\text { All } \\
0.012 \\
{[0.014]} \\
\text { County } \\
\end{array}$ & $\begin{array}{l}\text { South } \\
0.016 \\
{[0.013]} \\
\text { County } \\
\end{array}$ \\
\hline & \multicolumn{2}{|c|}{ Private bankers only } \\
\hline $\begin{array}{c}\text { L.gini coeff } \\
\text { Location fixed effects }\end{array}$ & $\begin{array}{c}\text { All } \\
-0.027 \\
{[0.021]} \\
\text { County }\end{array}$ & $\begin{array}{l}\text { South } \\
-0.010 \\
{[0.021]} \\
\text { County }\end{array}$ \\
\hline
\end{tabular}

$*$ denotes significance at $10 \% ; * *$ at $5 \%$ level and $* * *$ at $1 \%$ level.

Notes: The table presents robustness checks on individual linear regressions. The dependent variable is the number of banks per 1,000. All specifications contain county-level lagged variables:

$\ln$ (population), \% black, $\ln$ (manufacturing output per capita), $\ln$ (agricultural output per capita), $\ln$ (\# of farms). All specifications contain county-fixed effects, time fixed effects and the interaction between state fixed effects and time fixed effects. See text for sample composition and region definitions. Counties with more than 7,000 square miles, fewer than 20 farms, or any city of 25,000 or more are dropped. Dollar values are deflated to 1860 using Officer (2008). Robust standard are provided in brackets. ${ }^{*}$ denotes significance at $10 \%$; ** at $5 \%$ level and $* * *$ at $1 \%$ level. 
Table V: Cross-Sectional Regression Estimates Explaining Number of Banks (1870-1930)

\begin{tabular}{|c|c|c|c|c|c|c|}
\hline \multirow{4}{*}{ Gini coeff } & \multicolumn{6}{|c|}{1870} \\
\hline & \multicolumn{3}{|c|}{ All states } & \multicolumn{3}{|c|}{ South } \\
\hline & $-0.032 * * *$ & $-0.023 * *$ & -0.296 & $-0.023^{*}$ & $\begin{array}{l}-0.014 \\
\end{array}$ & -0.640 \\
\hline & [0.011] & {$[0.010]$} & {$[0.236]$} & {$[0.012]$} & {$[0.012]$} & {$[0.773]$} \\
\hline RR controls? & Yes & Yes & Yes & Yes & Yes & Yes \\
\hline Extra controls? & No & Yes & Yes & No & Yes & Yes \\
\hline Rainfall IV used? & No & No & Yes & No & No & Yes \\
\hline \multirow[t]{3}{*}{ F-stat on IV } & - & - & 5.206 & - & - & 0.784 \\
\hline & \multicolumn{6}{|c|}{1880} \\
\hline & \multicolumn{3}{|c|}{ All states } & \multicolumn{3}{|c|}{ South } \\
\hline \multirow[t]{2}{*}{ Gini coeff } & -0.019 & -0.008 & $-0.266^{* * * *}$ & $-0.033^{*}$ & $\begin{array}{l}-0.014 \\
\end{array}$ & $-0.258^{* * *}$ \\
\hline & {$[0.015]$} & {$[0.015]$} & [0.091] & {$[0.018]$} & {$[0.018]$} & {$[0.126]$} \\
\hline RR controls? & Yes & Yes & Yes & Yes & Yes & Yes \\
\hline Extra controls? & No & Yes & Yes & No & Yes & Yes \\
\hline Rainfall IV used? & No & No & Yes & No & No & Yes \\
\hline \multirow{3}{*}{ F-stat on IV } & - & - & 66.29 & - & - & 17.552 \\
\hline & \multicolumn{6}{|c|}{1890} \\
\hline & & All states & & & South & \\
\hline \multirow[t]{2}{*}{ Gini coeff } & $-0.200 * * *$ & $-0.153 * * *$ & $-2.533 * * *$ & -0.015 & 0.004 & $-1.013 * * *$ \\
\hline & [0.042] & {$[0.040]$} & {$[0.506]$} & {$[0.030]$} & {$[0.028]$} & [0.348] \\
\hline RR controls? & Yes & Yes & Yes & Yes & Yes & Yes \\
\hline Extra controls? & No & Yes & Yes & No & Yes & Yes \\
\hline Rainfall IV used? & No & No & Yes & No & No & Yes \\
\hline \multirow[t]{3}{*}{ F-stat on IV } & - & - & 38.137 & - & - & 14.902 \\
\hline & \multicolumn{6}{|c|}{1900} \\
\hline & & All states & & & South & \\
\hline \multirow{2}{*}{ Gini coeff } & -0.079 & 0.014 & $-0.718 * *$ & -0.098 & -0.032 & -0.271 \\
\hline & {$[0.065]$} & {$[0.064]$} & [0.279] & [0.084] & {$[0.085]$} & {$[0.167]$} \\
\hline RR controls? & Yes & Yes & Yes & Yes & Yes & Yes \\
\hline Extra controls? & No & Yes & Yes & No & Yes & Yes \\
\hline Rainfall IV used? & No & No & Yes & No & No & Yes \\
\hline \multirow[t]{3}{*}{ F-stat on IV } & - & - & 57.755 & - & - & 104.191 \\
\hline & \multicolumn{6}{|c|}{1910} \\
\hline & & All states & & & South & \\
\hline \multirow[t]{2}{*}{ Gini coeff } & $-0.303 * * *$ & -0.076 & $-1.838 * * *$ & $-0.262 * *$ & 0.030 & $-1.155^{* * *}$ \\
\hline & [0.070] & {$[0.071]$} & {$[0.342]$} & {$[0.109]$} & {$[0.129]$} & [0.204] \\
\hline RR controls? & Yes & Yes & Yes & Yes & Yes & Yes \\
\hline Extra controls? & No & Yes & Yes & No & Yes & Yes \\
\hline Rainfall IV used? & No & No & Yes & No & No & Yes \\
\hline F-stat on IV & - & - & 98.914 & - & - & 262.185 \\
\hline & & & & & & \\
\hline & & All states & & & South & \\
\hline Gini coeff & $-0.565 * * *$ & $-0.197 * *$ & $-2.279 * * *$ & $-0.526 * * *$ & -0.218 & $-1.733^{* * *}$ \\
\hline & [0.079] & {$[0.086]$} & [0.473] & [0.115] & {$[0.162]$} & {$[0.320]$} \\
\hline RR controls? & Yes & Yes & Yes & Yes & Yes & Yes \\
\hline Extra controls? & No & Yes & Yes & No & Yes & Yes \\
\hline Rainfall IV used? & No & No & Yes & No & No & Yes \\
\hline F-stat on IV & - & - & 66.569 & - & - & 123.03 \\
\hline & & & & & & \\
\hline & & All states & & & South & \\
\hline Gini coeff & $-0.364 * * *$ & $-0.202 * * *$ & $-0.428^{*}$ & $-0.158 * *$ & -0.017 & 0.095 \\
\hline & {$[0.048]$} & {$[0.053]$} & {$[0.245]$} & [0.063] & {$[0.075]$} & [0.141] \\
\hline RR controls? & Yes & Yes & Yes & Yes & Yes & Yes \\
\hline Extra controls? & No & Yes & Yes & No & Yes & Yes \\
\hline Rainfall IV used? & No & No & Yes & No & No & Yes \\
\hline F-stat on IV & - & - & 94.596 & - & - & 212.677 \\
\hline
\end{tabular}

$*$ denotes significance at $10 \% ; * *$ at $5 \%$ level and $* * *$ at $1 \%$ level.

Notes: The table presents individual decade cross-sectional regressions. The column headings provide the year. RR controls: population, land area, whether the county was on a large river or coast, fraction illiterate, fraction young, and fraction non-white, and state-fixed effects. Extra Controls $\ln$ (manufacturing output per capita), $\ln$ (agricultural output per capita), $\ln$ (\# of farms), fraction tenants, average rainfall, average temperature, and the standard deviation of temperature, maximum change in elevation, soil moisture, percent of clay in the soil. Counties with more than 7,000 square miles, fewer than 20 farms, or any city of 25,000 or more are dropped. Dollar values are deflated to 1860 using Officer (2008). Robust standard are provided in brackets. 
Table VI: Extending Panel Regressions Forward In Time

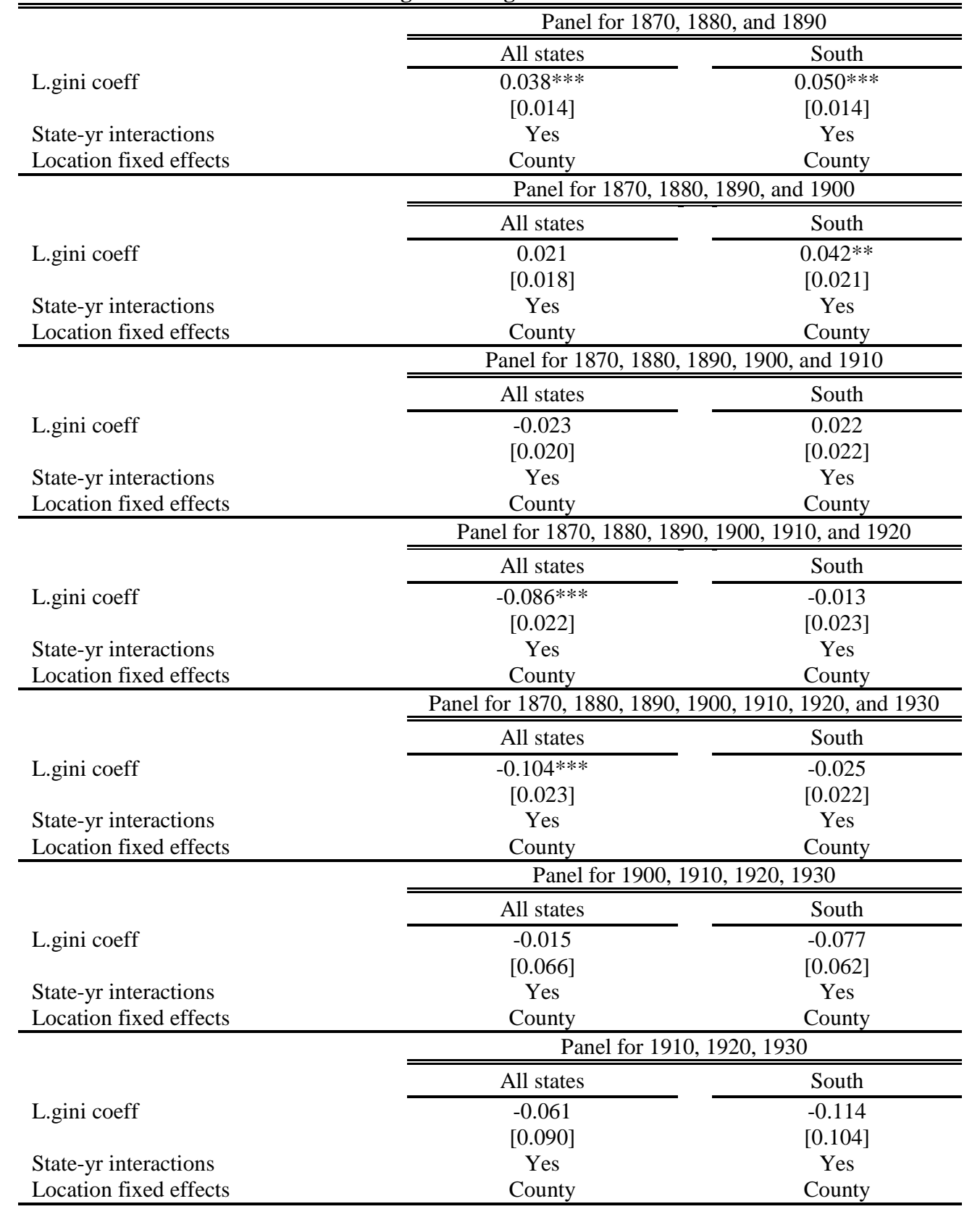

$*$ denotes significance at $10 \% ; * *$ at $5 \%$ level and $* * *$ at $1 \%$ level.

Notes: The table presents individual linear regressions. The column headings provide the panel years. All specifications contain county-level lagged variables: $\ln$ (population), fraction non-white $\ln$ (manufacturing output per capita), ln(agricultural output per capita), $\ln$ (\# of farms). All specifications contain county-fixed effects, time fixed effects and the interaction between state fixed effects and time fixed effects. See text for sample composition and region definitions. Counties with more than 7,000 square miles, fewer than 20 farms, or any city of 25,000 or more are dropped. Dollar values are deflated to 1860 using Officer (2008). Robust standard are provided in brackets. 

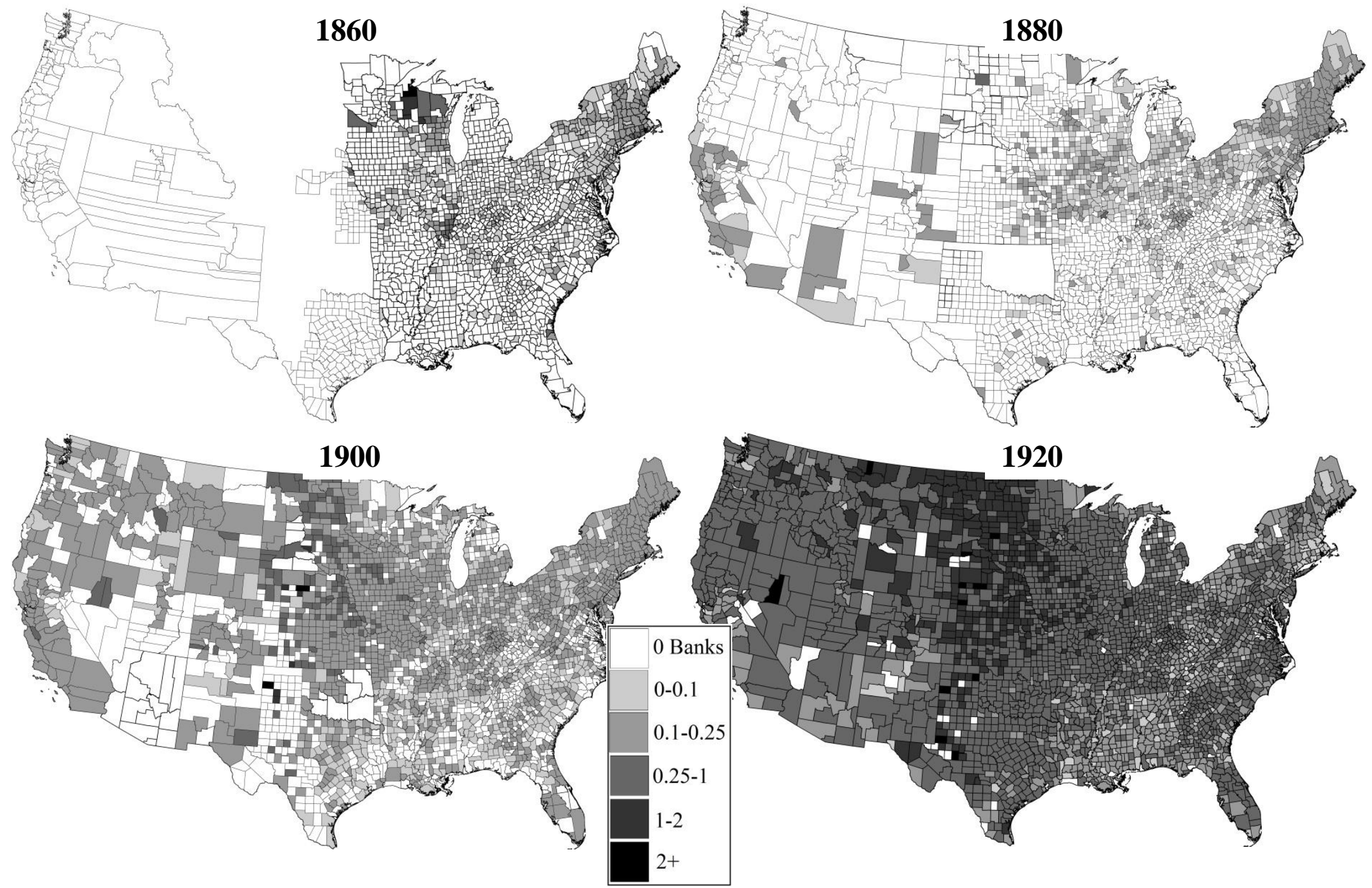

Figure I

Total Number of Banks Per Thousand People by County (1860-1920)

Notes: Displays the number of banks per thousand people in each county. County boundaries obtained from Minnesota Population Center (2004) and county population obtained from Haines (2004). See text for the sources of bank data. 

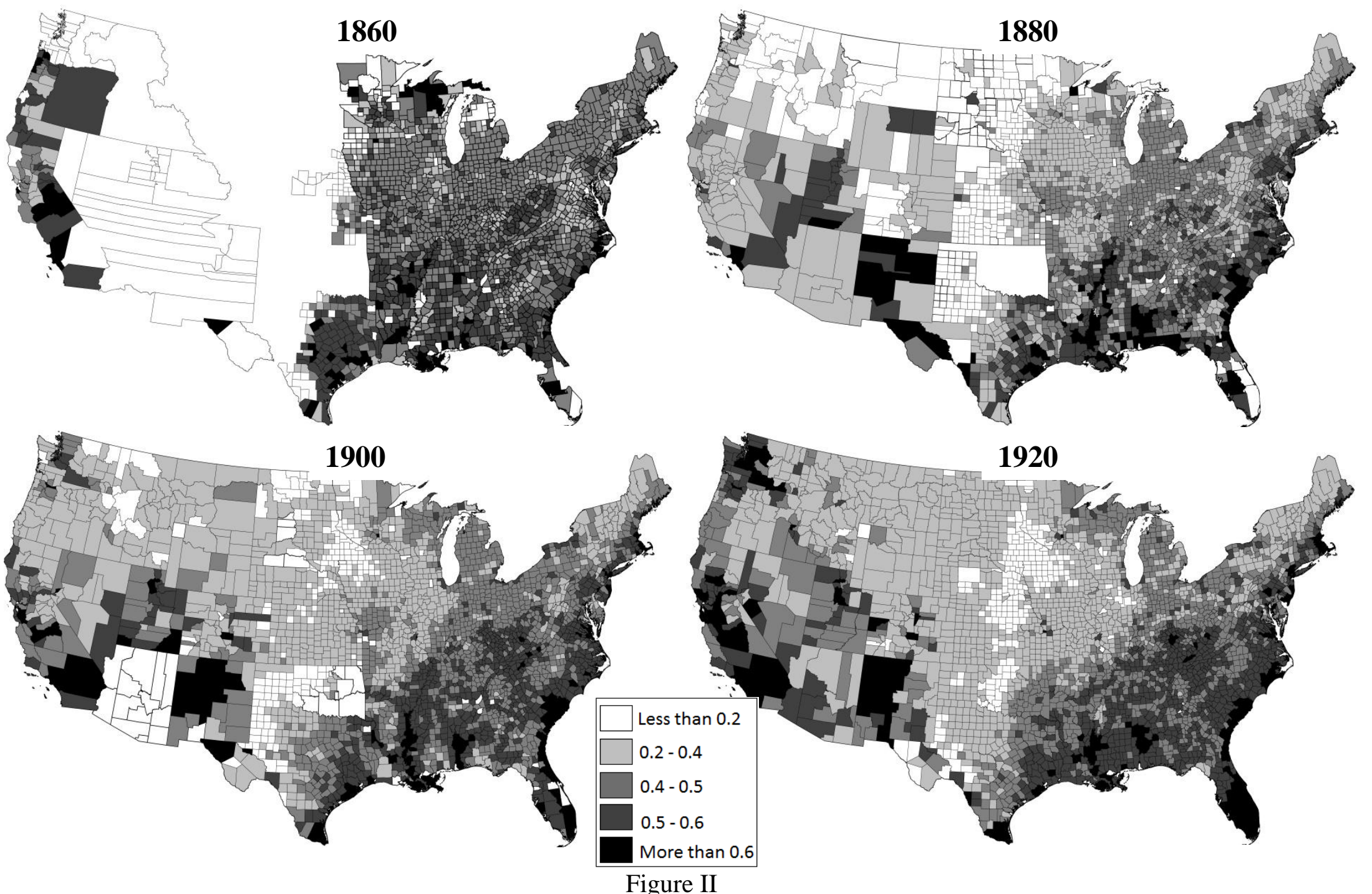

Gini Coefficient by County (1860-1920)

Notes: Displays county-level Gini coefficient. County boundaries obtained from Minnesota Population Center (2004), and Gini coefficient calculated from Haines (2004). 


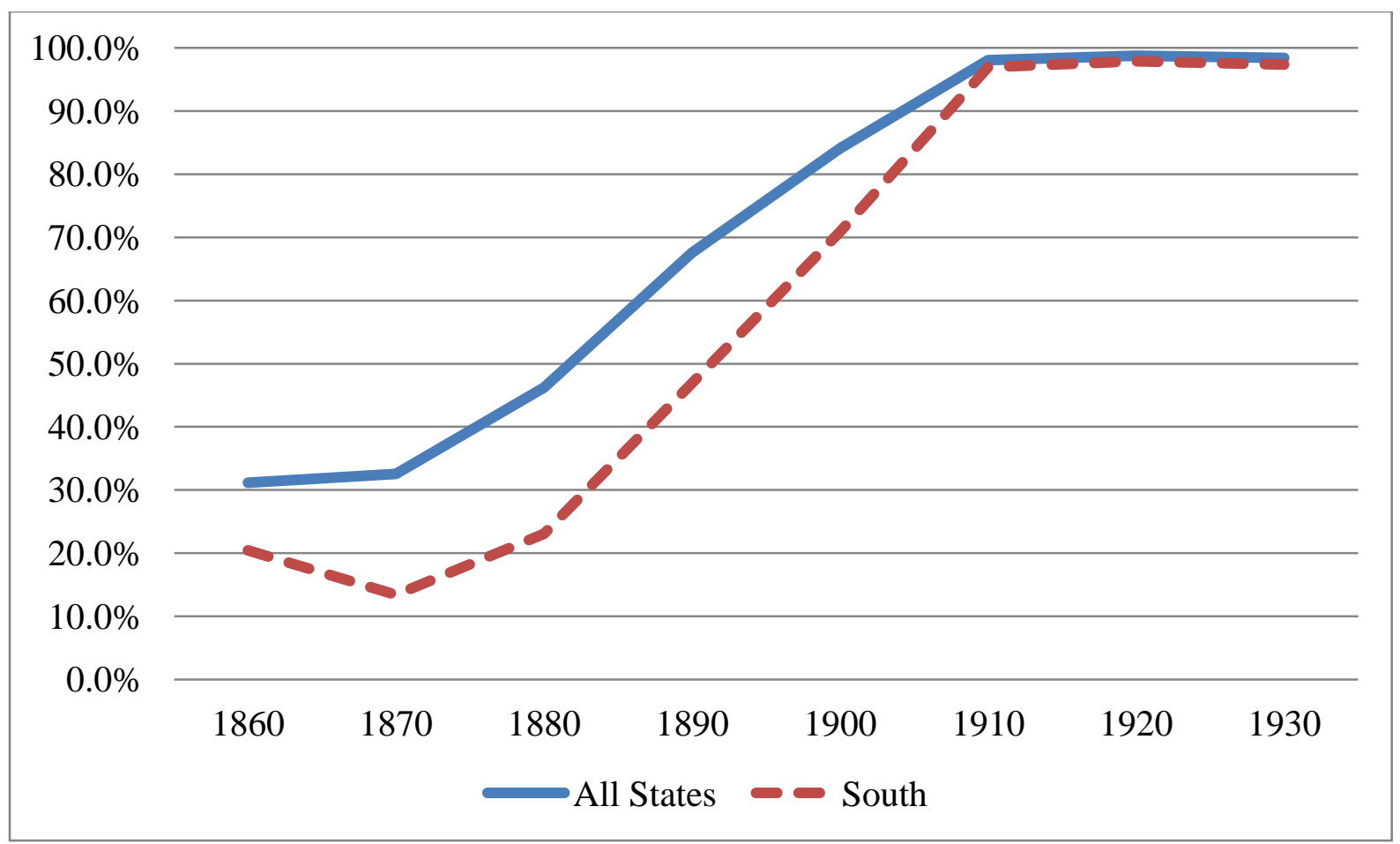

Figure III

Percent of Counties With At Least One Bank (1860-1930)

Notes: Figure presents the percent of counties that had at least one bank in the specified year. Counties are aggregated to their 1860 boundaries. See text for the sources of bank data. 